\title{
Spectroscopic (IR, Raman) and thermogravimetric studies of 3d-metal cinchomeronates and dinicotinates
}

\author{
G. Świderski ${ }^{1}$ • M. Kalinowska ${ }^{1}$ I. Rusinek ${ }^{2}$ • \\ M. Samsonowicz ${ }^{1} \cdot$ Z. Rzączyńska $^{2} \cdot$ W. Lewandowski ${ }^{1}$
}

Received: 28 November 2015/Accepted: 4 September 2016/Published online: 20 September 2016

(C) The Author(s) 2016. This article is published with open access at Springerlink.com

\begin{abstract}
In this work, the thermal and spectroscopic properties of $3 \mathrm{~d}$-metal $(\mathrm{Co}, \mathrm{Cu}, \mathrm{Zn}, \mathrm{Mn}, \mathrm{Ni}, \mathrm{Fe})$ and sodium salts with cinchomeronic acid (3,4-pyridinedicarboxylic acid) (3,4pda) and dinicotinic acid (3,5pyridinedicarboxylic acid) (3,5pda) were studied. The IR and Raman spectra were registered and analyzed in the range of $400-4000 \mathrm{~cm}^{-1}$. The thermogravimetric study of synthesized compounds was done. The degree of hydration and the products of thermal decomposition were estimated. Moreover, it was done the comparison between the effect of 3d-transition metal cations and sodium cation on the degree of perturbation or stabilization of the electronic system of pyridine molecule depending on the position of carboxylic group in the ring.
\end{abstract}

Keywords Nicotinic acid and derivatives $\cdot$ Cinchomeronic acid $\cdot$ Dinicotinic acid $\cdot$ Metal complexes $\cdot$ Spectroscopy (IR Raman)

Electronic supplementary material The online version of this article (doi:10.1007/s10973-016-5818-7) contains supplementary material, which is available to authorized users.

G. Świderski

swider30@gmail.com

$\triangle$ W. Lewandowski

w-lewando@wp.pl

1 Department of Chemistry, Bialystok University of Technology, Wiejska Street 45E, 15-351 Bialystok, Poland

2 Department of General and Coordination Chemistry, UMCS, M.C. Sklodowska Sq. 2, 20-031 Lublin, Poland

\section{Introduction}

Pyridinecarboxylic acids (picolinic, nicotinic and isonicotinic) are biologically important ligands incorporated into some enzymes, and they are active agents in some drugs as well [1-18]. In our previous work, we examined the effect of different metals (alkali [19-21], alkaline earth [22], 3dmetals [23]) on the electronic system of pyridinecarboxylic acids. Research shows that alkali and heavy toxic metals with low ionic potential disturb the aromatic system, while the 3d-transition metals stabilize the aromatic system pyridinecarboxylic acids.

This work is a continuation of our investigations on the metals effect on the electronic structure of pyridinecarboxylic acid. The study of metal complexes with nicotinic acid and cinchomeronic acid has shown that these complexes can have different types of metal-ligand coordination [24-26]. Whitfield et al. [24] studied the complexes of cobalt and nickel with 3,5-pyridinedicarboxylic acid. The complex of cobalt $\left(\mathrm{CoL} \cdot 2 \mathrm{H}_{2} \mathrm{O}\right)$ is monodentate binding. However, in the nickel complex $\left(\mathrm{NiL} \cdot \mathrm{H}_{2} \mathrm{O}\right)$, there are two types of bonds: monodentate and bidentate chelating. Łyszczek and Mazur studied the structures and thermal properties of lanthanide dinicotinates [25]. Studies have shown that the lanthanides form the types of coordination, such as monodentate, bidentate bridging and chelating bidentate. In the structure of calcium dinicotinate, there are two types of bonds-monodentate and bidentate chelating Starosta et al. [26]. In the structure of manganese cinchomeronate, there are two types of bonds-monodentate and bidentate bridging Tong et al. [27].

The specific objectives of the present study (along with the purpose of implementing the above-mentioned broader theme) are to: 
1. determine the composition studied complexes on the basis of elemental analysis and thermogravimetric data

2. propose the structure of the compounds on the basis of FT-IR and Raman spectral data

3. compare the change in electronic charge distribution as a result of complex formation.

In the present work, the impact of 3d-metals on the electron system of pyridinedicarboxylic acids (dinicotinic and cinchomeronic acids) (Fig. 1) was examined and thermal properties of metal complexes of these acids were determined.

\section{Experimental}

\section{Sample preparations}

3,4-pyridinedicarboxylates (3,4-pdc) and 3,5-pyridinedicarboxylates $(3,5-p d c)$ of 3 -d metal ions were prepared in water solution by adding disodium salts of each ligand to appropriate amount of 3 -d metal chlorides at $80{ }^{\circ} \mathrm{C}$ with continuous stirring for $2 \mathrm{~h}$ (molar ratio of sodium salts of ligands to the metal chlorides was 1:1 in case of divalent metal ions and 1.5:1 in case of trivalent metal). The mixtures were left for $24 \mathrm{~h}$ at room temperature. The precipitated solids were filtered off and washed with water to eliminate chloride ions. Disodium salts were obtained as microcrystals by adding the of sodium hydroxide solution $(0.1 \mathrm{M})$ to the stoichiometric amount of acid (molar ratio of ligand to the sodium hydroxide: 1:2). Salts were slowly evaporated at room temperature. After precipitation, the salt microcrystals were filtered and washed with a small amount of deionized water. Purity of the salts and complexes was confirmed by elemental analysis and IR spectra analysis. Substances were dried at $30^{\circ} \mathrm{C}$ under atmospheric pressure.

\section{Methods}

The FT-IR spectra were recorded with an Alfa (Bruker) spectrometer within the range of $400-4000 \mathrm{~cm}^{-1}$. The samples in the solid state were measured in $\mathrm{KBr}$ matrix pellets. FT-Raman spectra of solid samples were recorded in the range of $400-4000 \mathrm{~cm}^{-1}$ with a MultiRam (Bruker) spectrometer. Thermogravimetric analyses were conducted on the Setsys 16/18 analyzer in dynamic air atmosphere. Therefore, 6.0-8.0-mg samples were heated in the range of $30-800{ }^{\circ} \mathrm{C}$ in the ceramic crucibles using the heating rate of $10^{\circ} \mathrm{C} \mathrm{min}{ }^{-1}$. The TG, DTG and DSC curves were registered. The elementary analysis was carried out using the CHN 2400 PerkinElmer Analyzer. The water content was determined from the thermogravimetric curves.

\section{Results and discussion}

\section{Elemental analysis}

The composition of the synthesized complexes was determined by elemental analysis. The data are gathered in Tables 1 and 2. All the complexes prepared in accordance with the procedure presented in experimental section were hydrated. It was confirmed by thermal analysis. Complexes of manganese and zinc as well as sodium salts were white similarly as the ligands from which they were synthesized. Other complexes were colorful. The obtained complexes were poorly soluble in water. Synthesis was carried out several times to give a reaction yield of $60-80 \%$. The reaction yields for the different complexes are given in Tables 1 and 2 .

\section{Thermogravimetric analysis}

The complexes of 3,4-pyridinedicarboxylic and 3,5pyridinedicarboxylic acids with transition metal ions have the general formula: $\mathrm{M}\left[\left(\mathrm{C}_{5} \mathrm{NH}_{3}(\mathrm{COO})_{2}\right] \cdot \mathrm{nH}_{2} \mathrm{O}\right.$ where $\mathrm{M}=\mathrm{Mn}, \mathrm{Co}, \mathrm{Ni}, \mathrm{Cu}, \mathrm{Zn}(\mathrm{II})$ ions, $n=1-3$ and $\mathrm{Fe}_{2}\left[\left(\mathrm{C}_{5}\right.\right.$ $\left.\mathrm{NH}_{3}(\mathrm{COO})_{2}\right]_{3} \cdot \mathrm{nH}_{2} \mathrm{O}$ where $n=4$ or 6 . The complexes of both series are obtained as hydrated, crystalline well-defined compounds. The simultaneous TG/DTG/DSC curves in dynamic dry air atmosphere of all compounds are shown in Figs. 2-9. The analytical and thermoanalytical data for the synthesized compounds are given in Tables 1-4, respectively (Figs. 2-9). These results indicate the stoichiometry of two series of compounds, which are consistent with their general formulae.
Fig. 1 Structures of studied ligands<smiles>O=C(O)c1cccnc1</smiles>

3-pyridinecarboxylic acid nicotinic acid

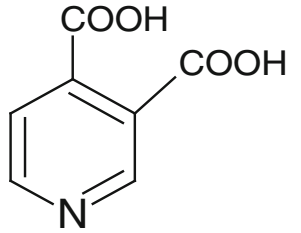

3,4-pyridinedicarboxylic acid cinchomeronic acid<smiles>O=C(O)c1cncc(C(=O)O)c1</smiles>

3,5-pyridinedicarboxylic acid dinicotinic acid 
Table 1 Elemental analysis, analytical and physical data for 3,4-pyridinedicarboxylates

\begin{tabular}{|c|c|c|c|c|c|c|c|c|c|c|}
\hline \multirow[t]{2}{*}{ Compound } & \multirow[t]{2}{*}{ Color } & \multirow[t]{2}{*}{ Yield/\% } & \multicolumn{2}{|c|}{ Content $\mathrm{C} / \%$} & \multicolumn{2}{|c|}{ Content $\mathrm{H} / \%$} & \multicolumn{2}{|c|}{ Content N/\% } & \multicolumn{2}{|c|}{ Content $\mathrm{M} / \%$} \\
\hline & & & Exp. & Calc. & Exp. & Calc. & Exp. & Calc. & Exp. & Calc. \\
\hline $\mathrm{Na}_{2} \mathrm{~L} \cdot \mathrm{H}_{2} \mathrm{O}$ & White & $70-75$ & 36.18 & 36.66 & 2.14 & 2.18 & 6.02 & 6.11 & 19.78 & 20.08 \\
\hline $\mathrm{MnL} \cdot \mathrm{H}_{2} \mathrm{O}$ & White & 70 & 35.16 & 35.29 & 2.21 & 2.10 & 5.69 & 5.88 & 22.33 & 23.08 \\
\hline $\mathrm{Fe}_{2} \mathrm{~L}_{3} \cdot 6 \mathrm{H}_{2} \mathrm{O}$ & Brown & $65-70$ & 35.10 & 35.15 & 2.07 & 2.09 & 5.97 & 6.11 & 16.50 & 16.89 \\
\hline $\mathrm{CoL} \cdot 1.5 \mathrm{H}_{2} \mathrm{O}$ & Violet & $65-70$ & 33.78 & 33.46 & 2.28 & 2.39 & 5.64 & 5.58 & 23.72 & 23.47 \\
\hline $\mathrm{NiL} \cdot 3 \mathrm{H}_{2} \mathrm{O}$ & Green & $60-65$ & 32.06 & 32.33 & 2.60 & 2.69 & 5.48 & 5.39 & 22.97 & 22.59 \\
\hline $\mathrm{CuL} \cdot \mathrm{H}_{2} \mathrm{O}$ & Blue & $65-70$ & 33.95 & 34.05 & 1.98 & 2.03 & 5.61 & 5.68 & 25.44 & 25.76 \\
\hline $\mathrm{ZnL} \cdot \mathrm{H}_{2} \mathrm{O}$ & White & $75-80$ & 33.49 & 33.80 & 2.13 & 2.01 & 5.47 & 5.63 & 25.56 & 26.31 \\
\hline
\end{tabular}

Table 2 Elemental analysis, analytical and physical data for 3,5-pyridinedicarboxylates

\begin{tabular}{|c|c|c|c|c|c|c|c|c|c|c|}
\hline \multirow[t]{2}{*}{ Compound } & \multirow[t]{2}{*}{ Color } & \multirow[t]{2}{*}{ Yield/\% } & \multicolumn{2}{|c|}{ Content $\mathrm{C} / \%$} & \multicolumn{2}{|c|}{ Content $\mathrm{H} / \%$} & \multicolumn{2}{|c|}{ Content N/\% } & \multicolumn{2}{|c|}{ Content $\mathrm{M} / \%$} \\
\hline & & & Exp. & Calc. & Exp. & Calc. & Exp. & Calc. & Exp. & Calc. \\
\hline $\mathrm{Na}_{2} \mathrm{~L} \cdot \mathrm{H}_{2} \mathrm{O}$ & White & $70-75$ & 36.44 & 36.66 & 1.93 & 2.18 & 5.88 & 6.11 & 19.32 & 20.08 \\
\hline $\mathrm{MnL} \cdot 2 \mathrm{H}_{2} \mathrm{O}$ & White & $65-70$ & 32.41 & 32.80 & 2.61 & 2.73 & 5.44 & 5.47 & 21.34 & 21.46 \\
\hline $\mathrm{Fe}_{2} \mathrm{~L}_{3} \cdot 4 \mathrm{H}_{2} \mathrm{O}$ & Brown & $60-70$ & 33.70 & 33.88 & 2.41 & 2.42 & 5.44 & 5.65 & 20.92 & 21.73 \\
\hline $\mathrm{CoL} \cdot 2 \mathrm{H}_{2} \mathrm{O}$ & Pink & $70-75$ & 32.71 & 32.30 & 2.57 & 2.69 & 5.37 & 5.38 & 22.62 & 22.66 \\
\hline $\mathrm{NiL} \cdot 3 \mathrm{H}_{2} \mathrm{O}$ & Green & $60-65$ & 35.29 & 35.34 & 1.29 & 1.31 & 6.01 & 6.12 & 20.73 & 21.11 \\
\hline $\mathrm{CuL} \cdot 0.5 \mathrm{H}_{2} \mathrm{O}$ & Blue & $60-70$ & 33.20 & 32.62 & 2.06 & 2.33 & 5.48 & 5.44 & 26.94 & 26.74 \\
\hline $\mathrm{ZnL} \cdot 1.5 \mathrm{H}_{2} \mathrm{O}$ & White & $75-80$ & 36.44 & 36.66 & 1.93 & 2.18 & 5.88 & 6.11 & 24.43 & 25.39 \\
\hline
\end{tabular}
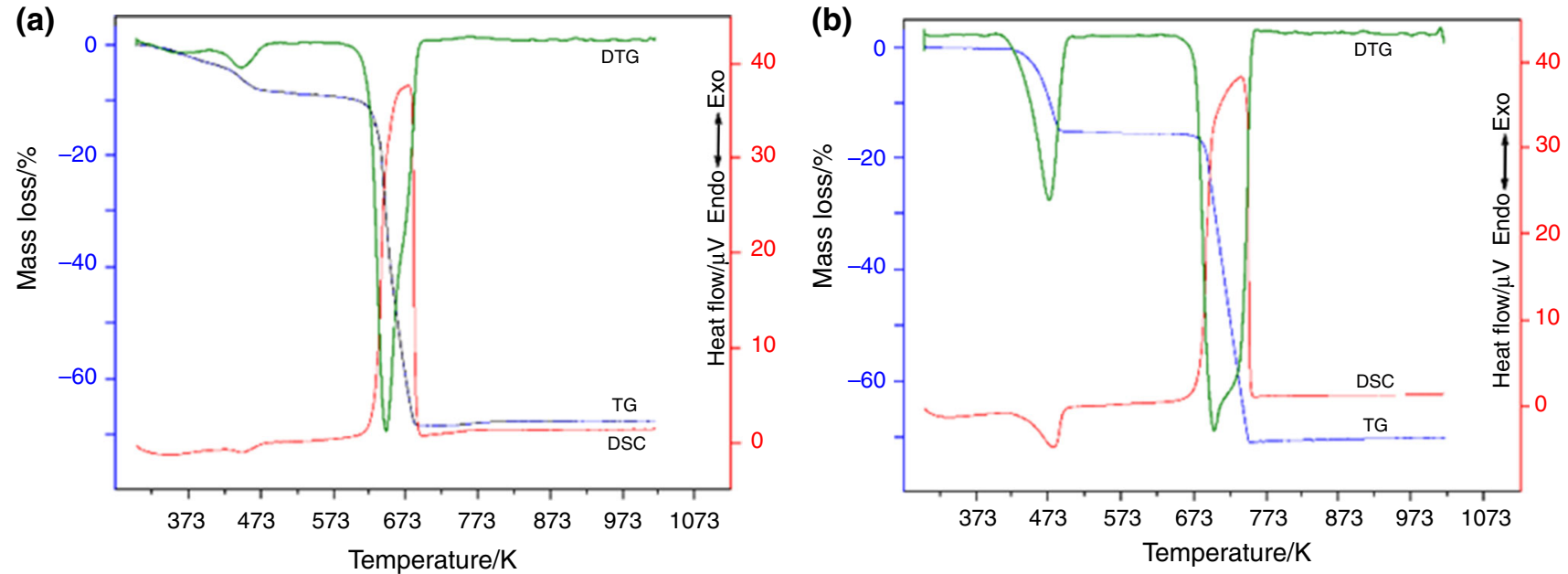

Fig. 2 TG/DTG/DSC curves of $\mathrm{Mn}(3,4-p d c) \cdot \mathrm{H}_{2} \mathrm{O}(\mathbf{a})$ and $\mathrm{Mn}(3,5-\mathrm{pdc})\left(\mathrm{H}_{2} \mathrm{O}\right)_{2}(\mathbf{b})$

Generally, the complexes of both series decompose in a similar way when heated in the two ground stages: the first stage is dehydration of the complexes with formation of more or less stable anhydrous compounds, and the second stage is decomposition of anhydrous compounds connected with oxidation of organic ligands and formation of metal oxides as residues.
The first stage the endothermic processes of dehydration occur for the majority of complexes in only one step at low temperatures with the onset temperatures of water evaporation of the hydrates in the range of 333-343 K. Their value points to outer-sphere character of water molecules in the structure of complexes. However, higher temperature of dehydration at $423-503 \mathrm{~K}$ as it takes place in the case of 
Table 3 Thermoanalytical results (TG,DTG,DSC) for complexes of 3,4-pyridinedicarboxylates

\begin{tabular}{|c|c|c|c|c|c|c|c|c|}
\hline \multirow[t]{2}{*}{ Complex } & \multirow[t]{2}{*}{ Stage } & \multirow{2}{*}{$\begin{array}{l}\mathrm{TG} \\
T_{\text {range/K }}\end{array}$} & \multirow{2}{*}{$\begin{array}{l}\text { DTG(DSC) } \\
T_{\text {max. peaks/K }}\end{array}$} & \multirow{2}{*}{$\begin{array}{l}\text { Peak nature/ } \\
\mathrm{kJ} / \mathrm{mol} \mathrm{H}_{2} \mathrm{O}\end{array}$} & \multicolumn{2}{|c|}{ Mass loss $/ \%$} & \multirow[t]{2}{*}{ Loss } & \multirow{2}{*}{$\begin{array}{l}\text { Final } \\
\text { residue }\end{array}$} \\
\hline & & & & & Calc. & Found & & \\
\hline \multirow[t]{2}{*}{$\mathrm{Mn}(3,4-\mathrm{pdc}) \cdot \mathrm{H}_{2} \mathrm{O}$} & I & $343-473$ & $453(448)$ & endo (39.3) & 8.75 & 8.05 & $\mathrm{H}_{2} \mathrm{O}$ & $\mathrm{MnO}$ \\
\hline & II & $613-688$ & $648(673)$ & exo & 70.21 & 69.38 & $\begin{array}{l}\mathrm{CO}_{2} ; \mathrm{CO} ; \text { py } \\
\text { (pyridine rings, } \\
\text { fragmentsof aromatic } \\
\text { rings) [30] }\end{array}$ & \\
\hline \multirow[t]{3}{*}{$\mathrm{Fe}_{2}(3,4-\mathrm{pdc})_{3} \cdot\left(\mathrm{H}_{2} \mathrm{O}\right)_{6}$} & I & $333-473$ & $373(373)$ & endo (22.7) & 15,10 & 15,60 & $\mathrm{H}_{2} \mathrm{O}$ & $\mathrm{Fe}_{2} \mathrm{O}_{3}$ \\
\hline & II & $573-653$ & $603(633)$ & exo & 74,80 & 77,60 & $\mathrm{CO}_{2} ; \mathrm{CO} ;$ py & \\
\hline & III & & $753(753)$ & exo & & & $\mathrm{CO}$ & \\
\hline \multirow[t]{2}{*}{$\mathrm{Co}(3,4-\mathrm{pdc}) \cdot\left(\mathrm{H}_{2} \mathrm{O}\right)_{1,5}$} & I & $333-473$ & $358(359)$ & endo (27.2) & 10.75 & 10.43 & $\mathrm{H}_{2} \mathrm{O}$ & $\mathrm{CoO}$ \\
\hline & II & $563-653$ & $613(643)$ & exo & 70.15 & 68.87 & $\mathrm{CO}_{2} ; \mathrm{CO} ;$ py & \\
\hline \multirow[t]{4}{*}[\mathrm{Ni}(3,4-\mathrm{pdc})(\mathrm{H}_{2}\mathrm{O})_{2}]{$\cdot \mathrm{H}_{2} \mathrm{O}$} & I & $343-398$ & $363(373)$ & endo $(29,3)$ & 10.76 & 9.95 & $1 \mathrm{H}_{2} \mathrm{O}$ & $\mathrm{NiO}$ \\
\hline & II & $398-453$ & $423(433)$ & endo & 19.43 & 20.77 & $2 \mathrm{H}_{2} \mathrm{O}$ & \\
\hline & III & $603-733$ & $643(673)$ & exo & 73.12 & 73.35 & $\mathrm{CO}_{2} ; \mathrm{CO} ;$ py & \\
\hline & IV & & $693(693)$ & exo & & & $\mathrm{CO}_{2} ; \mathrm{CO}$ & \\
\hline \multirow[t]{3}{*}{$\mathrm{Cu}(3,4-p d c) \cdot \mathrm{H}_{2} \mathrm{O}$} & I & $343-473$ & $423(348)$ & sł.endo $(49,7)$ & 7.29 & 7.00 & $\mathrm{H}_{2} \mathrm{O}$ & $\mathrm{CuO}$ \\
\hline & II & $513-533$ & $528(533)$ & exo & $\sim 40$ & 67.77 & $\mathrm{CO}_{2}$ & \\
\hline & III & $533-633$ & $623(623)$ & exo & 67.75 & & $\mathrm{CO}_{2} ; \mathrm{CO} ;$ py & \\
\hline \multirow[t]{4}{*}{$\mathrm{Zn}(3,4-\mathrm{pdc}) \cdot \mathrm{H}_{2} \mathrm{O}$} & I & $343-413$ & $358(353)$ & endo $(78,5)$ & 7.24 & 7.08 & $\mathrm{H}_{2} \mathrm{O}$ & $\mathrm{ZnO}$ \\
\hline & II & $573-763$ & $668(643)$ & exo & 67.30 & 68.08 & $\mathrm{CO}_{2} ;$ py & \\
\hline & III & & $728(733)$ & exo & & & $\mathrm{CO}_{2} ; \mathrm{CO}$ & \\
\hline & IV & & $873(873)$ & exo & & & $\mathrm{CO}_{2}$ & \\
\hline \multirow[t]{2}{*}{$\mathrm{Na}_{2}(3,4-\mathrm{pdc}) \cdot \mathrm{H}_{2} \mathrm{O}$} & I & $423-493$ & $463(468)$ & endo $(34,4)$ & 7.85 & 8.69 & $\mathrm{H}_{2} \mathrm{O}$ & $\mathrm{Na}_{2} \mathrm{CO}_{3}$ \\
\hline & II & $703-783$ & $733(743)$ & exo & - & - & $\mathrm{CO}_{2} ; \mathrm{CO} ; \mathrm{py}$ & \\
\hline
\end{tabular}
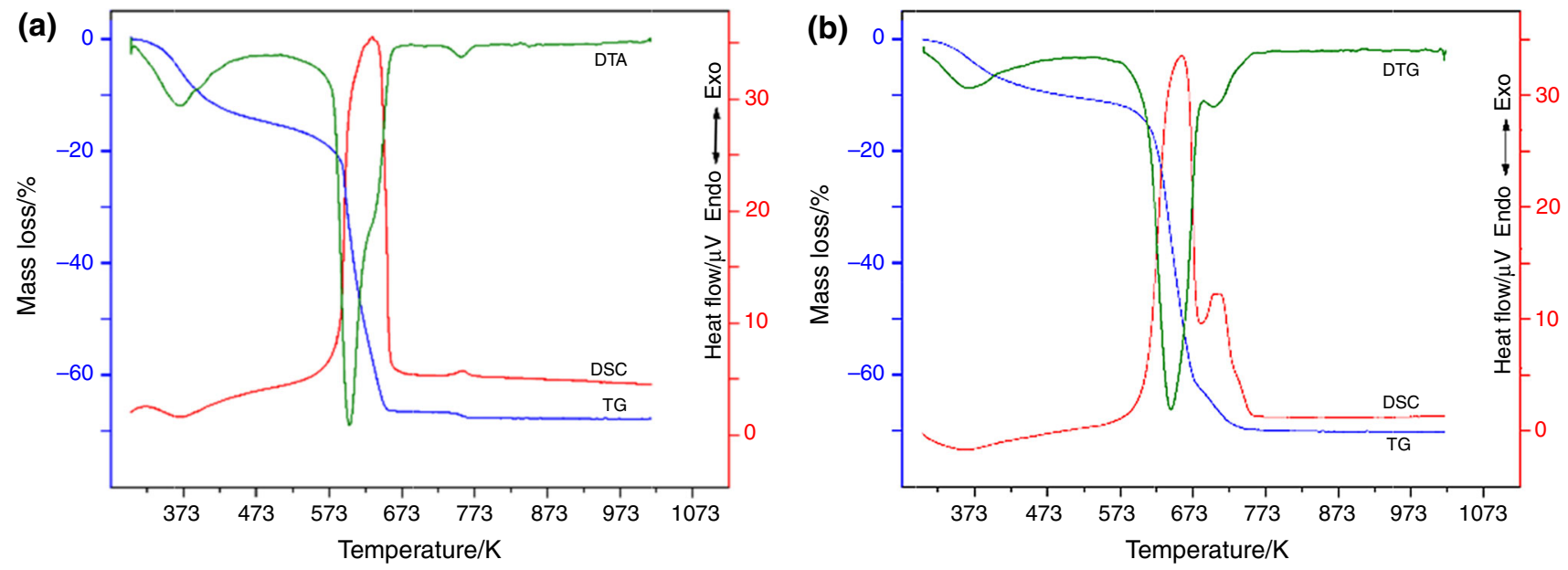

Fig. 3 TG/DTG/DSC curves of $\mathrm{Fe}_{2}(3,4-\mathrm{pdc})_{3}\left(\mathrm{H}_{2} \mathrm{O}\right)_{6}(\mathbf{a})$ and $\mathrm{Fe}_{2}(3,5-\mathrm{pdc})_{3}\left(\mathrm{H}_{2} \mathrm{O}\right)_{4}(\mathbf{b})$

$\mathrm{Mn}(3,5-\mathrm{pdc})\left(\mathrm{H}_{2} \mathrm{O}\right)_{2}$ complex points to the inner-sphere water molecules [28-30].

There are some complexes for which the dehydration is of double-stage character as for $\mathrm{Co}(3,5-\mathrm{pdc})\left(\mathrm{H}_{2} \mathrm{O}\right)_{2}$; $\mathrm{Ni}(3,4-\mathrm{pdc})\left(\mathrm{H}_{2} \mathrm{O}\right)_{3}$; and $\mathrm{Ni}(3,5-\mathrm{pdc})\left(\mathrm{H}_{2} \mathrm{O}\right)_{3}$ (Figs. 4b, 5a, b). For the $\mathrm{Co}(3,5-\mathrm{pdc})\left(\mathrm{H}_{2} \mathrm{O}\right)_{2}$ complex, there are two onset temperatures of dehydration at 343 and $403 \mathrm{~K}$, two peaks on the DTG and two endothermic peaks on DSC curves.
This fact as well as loss of mass allows to determine the formula of the complex as $\left[\mathrm{Co}(3,5-\mathrm{pdc})\left(\mathrm{H}_{2} \mathrm{O}\right)\right] \cdot\left(\mathrm{H}_{2} \mathrm{O}\right)$ which points to on one microcrystal- and one coordination water molecule. Two stages of dehydration are more visible on the TG, DTG and DSC curves of Ni(II) complexes.

For $\mathrm{Ni}(3,4-\mathrm{pdc})\left(\mathrm{H}_{2} \mathrm{O}\right)_{3}$ onsets of dehydration are at 343 and $398 \mathrm{~K}$, for $\mathrm{Ni}(3,5-\mathrm{pdc})\left(\mathrm{H}_{2} \mathrm{O}\right)_{3}$ at 343 and $493 \mathrm{~K}$. Dehydration at lower temperature $(343 \mathrm{~K})$ in both cases is 

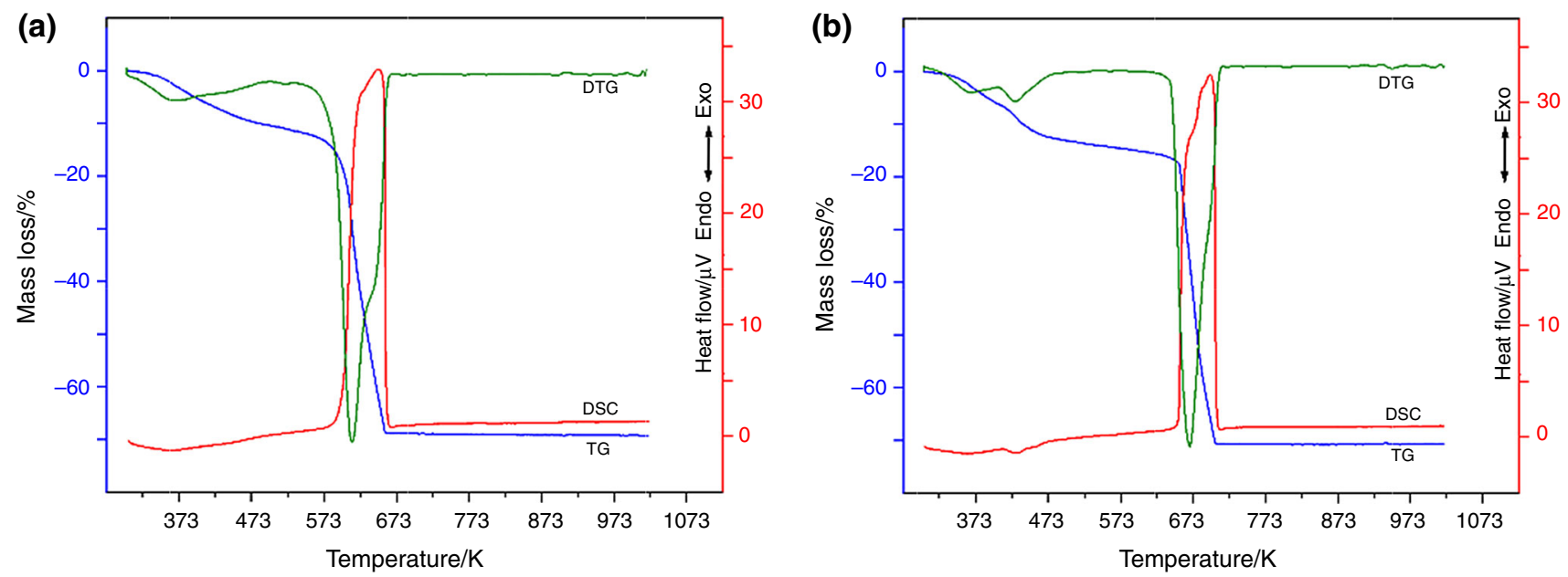

Fig. 4 TG/DTG/DSC curves of $\mathrm{Co}(3,4-\mathrm{pdc})\left(\mathrm{H}_{2} \mathrm{O}\right)_{1,5}(\mathbf{a})$ and $\left[\mathrm{Co}(3,5-\mathrm{pdc})\left(\mathrm{H}_{2} \mathrm{O}\right)\right] \cdot \mathrm{H}_{2} \mathrm{O}(\mathbf{b})$
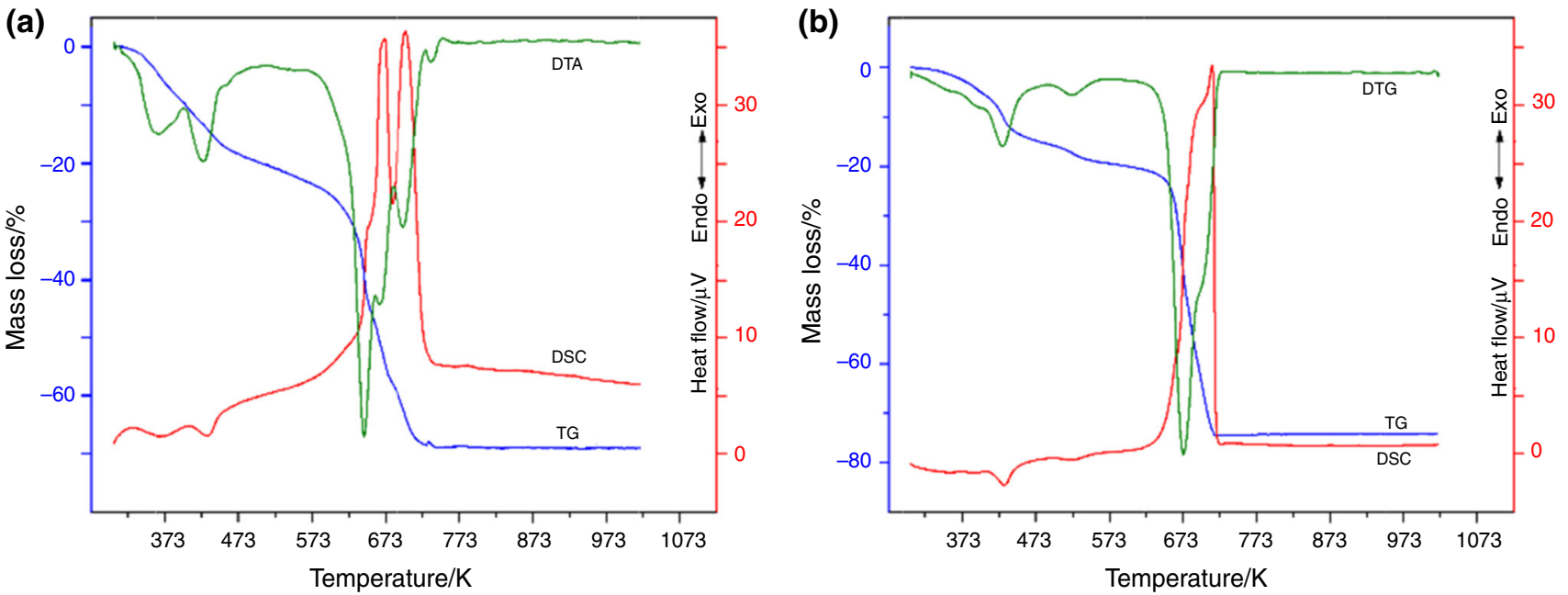

Fig. 5 TG/DTG/DSC curves of $\left[\mathrm{Ni}(3,5-\mathrm{pdc})\left(\mathrm{H}_{2} \mathrm{O}\right)_{2}\right] \cdot \mathrm{H}_{2} \mathrm{O}$ (a) and $\left[\mathrm{Ni}(3,5-\mathrm{pdc})\left(\mathrm{H}_{2} \mathrm{O}\right)\right] \cdot 2 \mathrm{H}_{2} \mathrm{O}(\mathbf{b})$

connected with a loss of outer-sphere water, but dehydration at higher temperatures ( 398 and $493 \mathrm{~K}$ ) is connected with a loss of coordination, inner-sphere water in the complex structures. Similarly to the Co(II) complex, two peaks on the DTG and DSC curves as well as calculated and found loss of mass allow to determine the formulae of complexes as $\left[\mathrm{Ni}(3,4-\mathrm{pdc})\left(\mathrm{H}_{2} \mathrm{O}\right)_{2}\right]\left(\mathrm{H}_{2} \mathrm{O}\right)$ and $[\mathrm{Ni}(3,5-$ $\left.\mathrm{pdc})\left(\mathrm{H}_{2} \mathrm{O}\right)\right] \cdot 2 \mathrm{H}_{2} \mathrm{O}$.

Analysis of the TG/DTG curves course indicates that after dehydration the formed anhydrous complexes are not generally stable and the TG curves show a slight but systematic loss in mass. The complex of $\mathrm{Mn}$ (II) is the most stable in the series of complexes with 3,4pda ligand (Fig. 2a), while the complexes of $\mathrm{Mn}$ (II) and $\mathrm{Zn}(\mathrm{II})$ are the most stable in the series with 3,5-pda ligand (Figs. $2 \mathrm{~b}$ and $7 \mathrm{~b}$ ). The complexes of 3,5-pda ligand seem to be more stable, and the onset temperatures for the decomposition of the anhydrous compounds, except for $\mathrm{Fe}$ (III) and $\mathrm{Cu}$ (II), are higher than those for 3,4pda ligand about 50-90 K (Tables 3 and 4). It can be due to more symmetric charge distribution in the complexes with 3,5-pdca ligand.

The anhydrous compounds of $\mathrm{Mn}(\mathrm{II}), \mathrm{Fe}(\mathrm{III}), \mathrm{Co}(\mathrm{II})$ and $\mathrm{Ni}(\mathrm{II})$ with 3,4pda and 3,4pda ligands above $600 \mathrm{~K}$ decompose in one step which correspond to the sharp exothermic peaks at about $700 \mathrm{~K}$ which can be also attributed to oxidation of organic matter and the gaseous products that evolve during thermal decomposition. In the case of Ni(3,4-pdc) complex (Fig. 5A), the exothermic peak splits into two. Processes of decomposition of anhydrous $\mathrm{Cu}(\mathrm{II})$ complexes of both ligands proceed in two stages (Fig. 6a, b). In both cases, the first step is connected with about $40 \%$ mass loss and the second one leads to $\mathrm{CuO}$ formation. The first step is attributed to small, but the second to large exothermic effects. The large effect is attributed to the oxidation of carbonaceous residue, formed in the former step [31]. 
Table 4 Thermoanalytical results (TG,DTG,DSC) for complexes of 3,5-pyridinedicarboxylates

\begin{tabular}{|c|c|c|c|c|c|c|c|c|}
\hline \multirow[t]{2}{*}{ Complex } & \multirow[t]{2}{*}{ Stage } & \multirow{2}{*}{$\begin{array}{l}\mathrm{TG} \\
T_{\text {range/K }}\end{array}$} & \multirow{2}{*}{$\begin{array}{l}\mathrm{DTG}(\mathrm{DSC}) \\
T_{\text {max. peaks } / \mathrm{K}}\end{array}$} & \multirow{2}{*}{$\begin{array}{l}\text { Peak nature/ } \\
\mathrm{kJ} / \mathrm{mol} \mathrm{H}_{2} \mathrm{O}\end{array}$} & \multicolumn{2}{|c|}{ Mass loss $/ \%$} & \multirow[t]{2}{*}{ Loss } & \multirow{2}{*}{$\begin{array}{l}\text { Final } \\
\text { residue }\end{array}$} \\
\hline & & & & & Calc. & Found & & \\
\hline \multirow[t]{2}{*}{$\mathrm{Mn}(3,5-\mathrm{pdc}) \cdot\left(\mathrm{H}_{2} \mathrm{O}\right)_{2}$} & I & $423-503$ & $473(483)$ & endo (50.0) & 14.06 & 15.07 & $\mathrm{H}_{2} \mathrm{O}$ & $\mathrm{MnO}$ \\
\hline & II & $663-748$ & 703(728) & exo & 71.84 & 70.81 & $\begin{array}{l}\mathrm{CO}_{2} ; \mathrm{CO} ; \text { py } \\
\text { (pyridine rings, } \\
\text { fragmentsof aromatic } \\
\text { rings)[30] }\end{array}$ & \\
\hline \multirow[t]{2}{*}{$\mathrm{Fe}_{2}(3,5-\mathrm{pdc})_{3} \cdot\left(\mathrm{H}_{2} \mathrm{O}\right)_{4}$} & I & $343-423$ & $358(363)$ & endo(33.2) & 10.60 & 10.10 & $\mathrm{H}_{2} \mathrm{O}$ & $\mathrm{Fe}_{2} \mathrm{O}_{3}$ \\
\hline & II & $573-748$ & $643(653)$ & exo & 76,48 & 74,85 & $\mathrm{CO}_{2} ; \mathrm{CO} ;$ py & \\
\hline \multirow[t]{3}{*}[\mathrm{Co}(3,5-\mathrm{pdc})(\mathrm{H}_{2}\mathrm{O})]{$\cdot \mathrm{H}_{2} \mathrm{O}$} & I & $343-393$ & $363(363)$ & endo(32.5) & 6.92 & 7.00 & $\mathrm{H}_{2} \mathrm{O}$ & $\mathrm{CoO}$ \\
\hline & II & $403-463$ & $433(433)$ & endo & 12.50 & 12.31 & $\mathrm{H}_{2} \mathrm{O}$ & \\
\hline & III & $636-733$ & $668(693)$ & exo & 70.18 & 70.69 & $\mathrm{CO}_{2} ; \mathrm{CO} ;$ py & \\
\hline \multirow[t]{3}{*}[\mathrm{Ni}(3,5-\mathrm{pdc})(\mathrm{H}_{2}\mathrm{O})]{$\cdot 2 \mathrm{H}_{2} \mathrm{O}$} & I & $343-443$ & $423(430)$ & endo(24.1) & 12.94 & 13.00 & $2 \mathrm{H}_{2} \mathrm{O}$ & $\mathrm{NiO}$ \\
\hline & II & $493-543$ & $513(523)$ & endo & 19.42 & 19.10 & $1 \mathrm{H}_{2} \mathrm{O}$ & \\
\hline & III & $636-713$ & $673(713)$ & exo & 73.14 & 73.47 & $\mathrm{CO}_{2} ; \mathrm{CO} ;$ py & \\
\hline \multirow[t]{3}{*}{$\mathrm{Cu}(3,5-\mathrm{pdc}) \cdot\left(\mathrm{H}_{2} \mathrm{O}\right)_{0,5}$} & I & $323-393$ & $343(351)$ & endo(21.0) & 3.79 & 4.02 & $\mathrm{H}_{2} \mathrm{O}$ & $\mathrm{CuO}$ \\
\hline & II & $523-573$ & $563(563)$ & exo & $\sim 45$ & 64.94 & $\mathrm{CO}_{2}$ & \\
\hline & III & $573-748$ & $693(693)$ & exo & 66.73 & & $\mathrm{CO}_{2} ; \mathrm{CO} ;$ py & \\
\hline \multirow[t]{3}{*}{$\mathrm{Zn}(3,5-\mathrm{pdc}) \cdot\left(\mathrm{H}_{2} \mathrm{O}\right)_{1,5}$} & I & $343-393$ & $368(353)$ & endo(18.6) & 3.50 & 3.30 & $\mathrm{H}_{2} \mathrm{O}$ & $\mathrm{ZnO}$ \\
\hline & II & $393-493$ & $443(447)$ & endo & 10.10 & 10.48 & $\mathrm{H}_{2} \mathrm{O}$ & \\
\hline & II & $663-753$ & $738(743)$ & exo & 68.39 & 68.72 & $\mathrm{CO}_{2} ; \mathrm{CO} ;$ py & \\
\hline \multirow[t]{2}{*}{$\mathrm{Na}_{2}(3,5-\mathrm{pdc}) \cdot \mathrm{H}_{2} \mathrm{O}$} & I & $393-443$ & $423(423)$ & endo (38.8) & 7.86 & 8.03 & $\mathrm{H}_{2} \mathrm{O}$ & $\mathrm{Na}_{2} \mathrm{CO}_{3}$ \\
\hline & II & $728-798$ & 773(793) & exo & 53.73 & 53.19 & $\mathrm{CO}_{2} ; \mathrm{CO} ;$ py & \\
\hline
\end{tabular}
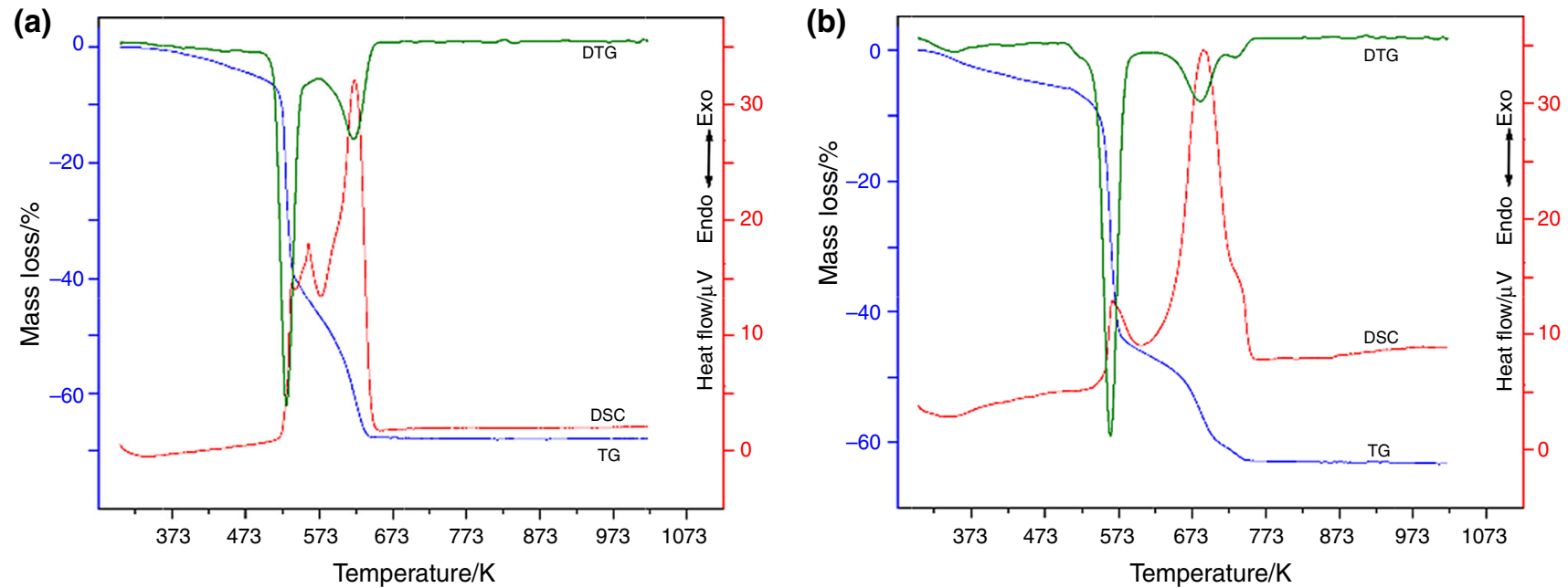

Fig. $6 \mathrm{TG} / \mathrm{DTG} / \mathrm{DSC}$ curves of $\mathrm{Cu}(3,4-\mathrm{pdc}) \cdot \mathrm{H}_{2} \mathrm{O}(\mathbf{a})$ and $\mathrm{Cu}(3,5-\mathrm{pdc})\left(\mathrm{H}_{2} \mathrm{O}\right)_{0,5}(\mathbf{b})$

Thermal decomposition of both $\mathrm{Zn}$ (II) complexes proceeds in a different way. The $\mathrm{Zn}(3,4-\mathrm{pdc}) \cdot \mathrm{H}_{2} \mathrm{O}$ complex at $573 \mathrm{~K}$ undergoes decomposition and oxidation with two exothermic effects and next oxidation of carbonaceous residue with the exothermic effect at $873 \mathrm{~K}$. The $\mathrm{Zn}(3,5-$ pdc) $\cdot \mathrm{H}_{2} \mathrm{O}$ complex is more stable, and at the temperature higher by about $100 \mathrm{~K}$ decomposition and oxidation take place in one step without intermediates products. In all complexes of both series, the total mass loss above $800 \mathrm{~K}$ corresponds to formation of metal oxides $\left(\mathrm{MO} ; \mathrm{Fe}_{2} \mathrm{O}_{3}\right)$ as final residues.

Additionally the simultaneous TG/DTG/DSC curves in dynamic dry air atmosphere of free 3,4-pyridinedicarboxylic and 3,5-pyridinedicarboxylic acids are presented in Fig. 8a, b. In both cases, these curves show total mass loss due to heating but in one step for 3,4- and in two steps for 3,5-pyridinedicarboxylic acid. The beginning of mass loss for 3,4-pdc acid starts at $473 \mathrm{~K}$, and the maximum of mass 

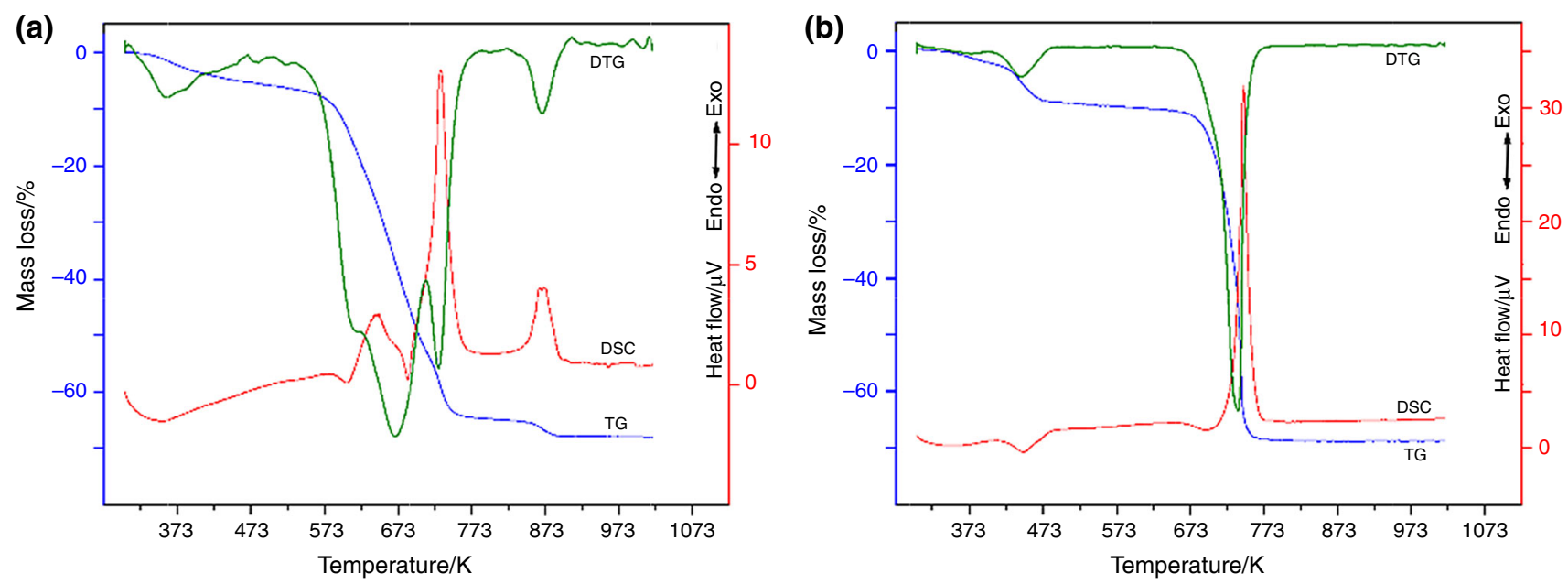

Fig. 7 TG/DTG/DSC curves of $\mathrm{Zn}(3,4-p d c) \cdot \mathrm{H}_{2} \mathrm{O}$ (a) and $\mathrm{Zn}(3,5-\mathrm{pdc})\left(\mathrm{H}_{2} \mathrm{O}\right)_{1,5}$ (b)
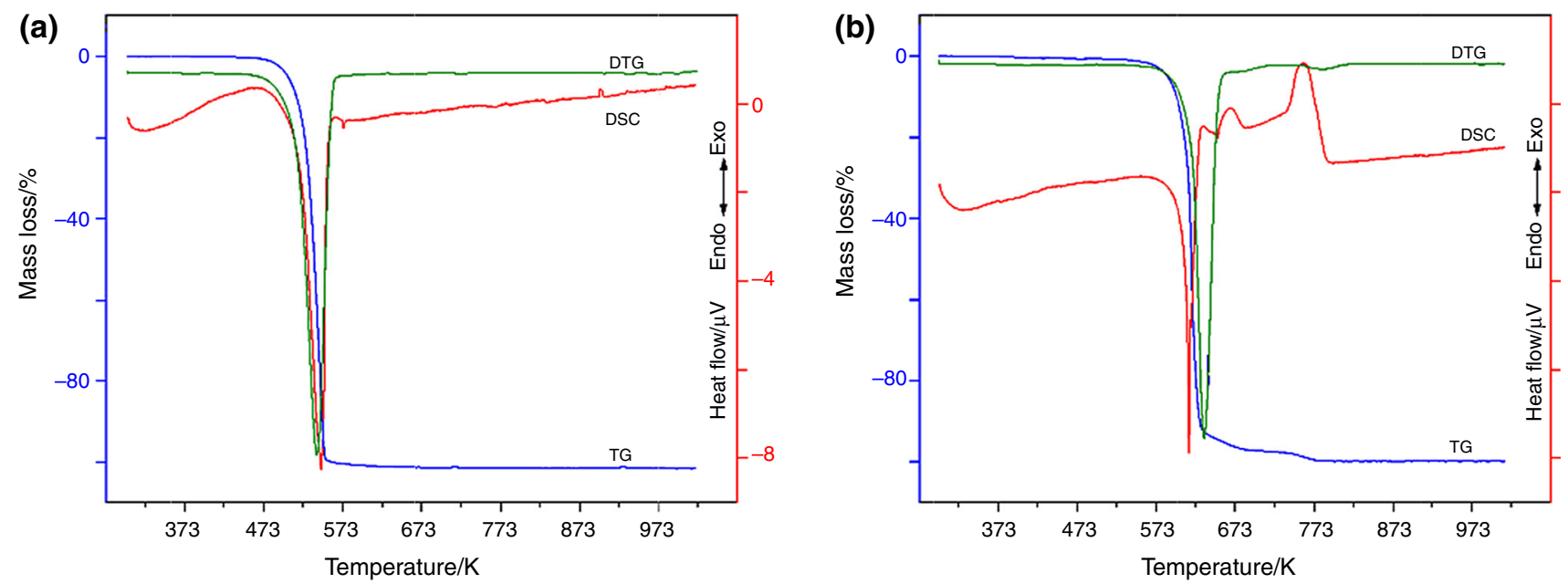

Fig. 8 TG/DTG/DSC curves of 3,4-pdc (a) and 3,5-pdc (b)

loss is observed at $558 \mathrm{~K}$ with the simultaneous large endothermic effect with the maximum at $563 \mathrm{~K}$. At $573 \mathrm{~K}$ the process is over. The endothermic peak at $563 \mathrm{~K}$ on the DSC curve is attributed to the melting of acid and partial evaporation as well as decarboxylation and decomposition $[31,32]$. The 3,5pda is more stable, and the beginning of mass loss is observed at $523 \mathrm{~K}$ with the maximum at $608 \mathrm{~K}$ and the endothermic effect at $623 \mathrm{~K}$. At $633 \mathrm{~K}$ the carbonaceous residue is formed and the exothermic peak at $753 \mathrm{~K}$ is attributed to its oxidation.

Disodium 3,4- and 3,5-pirydinedicarboxylates were necessary as the models for spectroscopic examination of complexes. They were obtained both as monohydrate microcrystalline compounds, but their thermal properties differ significantly. The thermal analysis of $\mathrm{Na}_{2}(3,4-$ pdc) $\cdot \mathrm{H}_{2} \mathrm{O}$ exhibits three mass loss steps. The lower temperature mass $(8.0 / 7.9 \%)$ at $423-493 \mathrm{~K}$ corresponds to the dehydration with a loss of one molecule of water resulting in the endothermic peak. Anhydrous compound is stable to about $693 \mathrm{~K}$. In this range of temperatures, the salts $\mathrm{Na}_{2}(3,4-$ pdc $) \cdot \mathrm{H}_{2} \mathrm{O}$ and $\mathrm{Na}_{2}(3,5-$ pdc $) \cdot \mathrm{H}_{2} \mathrm{O}$ exhibit the same way of decomposition but the anhydrous salt $\mathrm{Na}_{2}(3,5-$ pdc) is a bit more stable (up to $723 \mathrm{~K}$ ). Further heating causes gradual decomposition and oxidation of anhydrous salts but in different ways. The anhydrous salt $\mathrm{Na}_{2}$ (3,4-pdc) decomposes in two steps with the mass loss at range of $733 \mathrm{~K}$ and about $873 \mathrm{~K}$. The exothermic process with three peaks at $760 ; 765$; and $773 \mathrm{~K}$ is attributed to oxidation of the organic matter and gaseous products evolved during the thermal decomposition and oxidation. In the case of $\mathrm{Na}_{2}(3,5-\mathrm{pdc})$, the thermal decomposition occurs at $773 \mathrm{~K}$ in one step. The total mass loss (53.73/ 

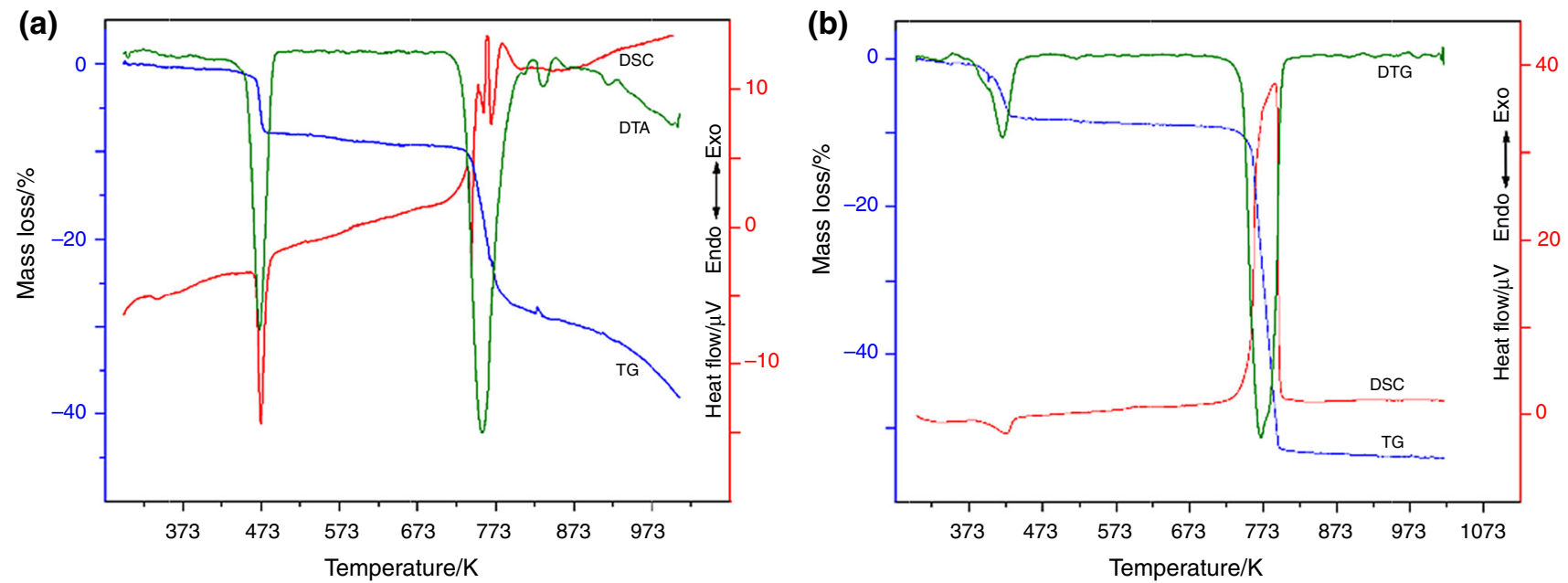

Fig. 9 TG/DTG/DSC curves of $\mathrm{Na}_{2}\left(3,4-\right.$ pdc) $\cdot \mathrm{H}_{2} \mathrm{O}$ (a) and $\mathrm{Na}_{2}\left(3,5-\right.$ pdc) $\cdot \mathrm{H}_{2} \mathrm{O}(\mathbf{b})$

Table 5 Spectral parameters from the IR and Raman spectra of 3,4- and 3,5-pyridinedicarboxylates

\begin{tabular}{|c|c|c|c|c|c|c|c|c|}
\hline \multicolumn{2}{|l|}{ Compound } & $v_{\mathrm{as}}\left(\mathrm{COO}^{-}\right)$ & $v_{\mathrm{sym}}\left(\mathrm{COO}^{-}\right)$ & $\Delta v$ & $\begin{array}{l}\beta_{\text {sym }} \\
\left(\mathrm{COO}^{-}\right)\end{array}$ & $\begin{array}{l}\beta_{\mathrm{as}} \\
\left(\mathrm{COO}^{-}\right)\end{array}$ & $\Delta \beta$ & Proposed type of coordination \\
\hline \multicolumn{9}{|c|}{ 3,4-pyridinedicarboxylates } \\
\hline \multirow[t]{2}{*}{$\mathrm{Na}_{2} \mathrm{~L} \cdot \mathrm{H}_{2} \mathrm{O}$} & IR & 1602 vs, 1585 vs & 1411 vs, $1381 \mathrm{~s}$ & 191,204 & $834 \mathrm{~s}$ & $433 \mathrm{~s}$ & 401 & \\
\hline & Raman & $1606 \mathrm{~s}, 1581 \mathrm{~m}$ & $1424 \mathrm{~s}, 1382 \mathrm{~m}$ & 182,199 & $840 \mathrm{~m}$ & $431 \mathrm{vw}$ & 409 & \\
\hline \multirow[t]{2}{*}{$\mathrm{MnL} \cdot \mathrm{H}_{2} \mathrm{O}$} & IR & 1571 vs & 1406 vs & 165 & $840 \mathrm{~m}$ & $469 \mathrm{~m}$ & 381 & Bidentate chelation \\
\hline & Raman & $1575 \mathrm{~m}$ & 1411 vs & 164 & $844 \mathrm{~m}$ & $456 \mathrm{w}$ & 388 & \\
\hline $\mathrm{Fe}_{2} \mathrm{~L}_{3} \cdot 3 \mathrm{H}_{2} \mathrm{O}$ & IR & 1576 vs, 1558 vs & 1401 vs & 175,157 & $834 \mathrm{~m}$ & $483 \mathrm{~s}$ & 351 & Bidentate chelation \\
\hline $\mathrm{CoL} \cdot 1.5 \mathrm{H}_{2} \mathrm{O}$ & IR & 1607 vs, 1585 vs & 1405 vs & 202,180 & $840 \mathrm{w}$ & $477 \mathrm{w}$ & 363 & Bidentate chelation \\
\hline $\mathrm{NiL} \cdot 2 \mathrm{H}_{2} \mathrm{O}$ & IR & 1585 vs & 1405 vs & 180 & $836 \mathrm{~m}$ & $456 \mathrm{~m}$ & 386 & Bidentate chelation \\
\hline $\mathrm{CuL} \cdot \mathrm{H}_{2} \mathrm{O}$ & IR & 1620 vs, 1585 vs & 1386 vs & 234,199 & $837 \mathrm{w}$ & $499 \mathrm{w}$ & 338 & Bidentate bridging and monodentate \\
\hline \multirow[t]{2}{*}{$\mathrm{ZnL} \cdot \mathrm{H}_{2} \mathrm{O}$} & IR & 1610 vs, 1598 vs & 1392 vs & 228,206 & $838 \mathrm{w}$ & $482 \mathrm{w}$ & 356 & Monodentate \\
\hline & Raman & $1609 \mathrm{~s}, 1588 \mathrm{~m}$ & $1401 \mathrm{~s}$ & 208,187 & $840 \mathrm{~s}$ & $487 \mathrm{w}$ & 357 & \\
\hline \multicolumn{9}{|c|}{ 3,5-pyridinedicarboxylates } \\
\hline \multirow[t]{2}{*}{$\mathrm{Na}_{2} \mathrm{~L} \cdot \mathrm{H}_{2} \mathrm{O}$} & IR & 1644 vs & 1377 vs & 267 & $824 \mathrm{w}$ & $425 \mathrm{~m}$ & 399 & \\
\hline & Raman & $1665 \mathrm{~m}$ & $1376 \mathrm{vw}$ & 289 & $825 \mathrm{~m}$ & $414 \mathrm{w}$ & 411 & \\
\hline \multirow[t]{2}{*}{$\mathrm{MnL} \cdot 2 \mathrm{H}_{2} \mathrm{O}$} & IR & 1614 vs, 1603 vs & 1398 vs & 216,205 & $848 \mathrm{~m}$ & $440 \mathrm{~m}$ & 404 & Bidentate chelation \\
\hline & Raman & $1604 \mathrm{~m}$ & $1393 \mathrm{w}$ & 211 & $852 \mathrm{~m}$ & $427 \mathrm{w}$ & 425 & \\
\hline $\mathrm{Fe}_{2} \mathrm{~L}_{3} \cdot 4 \mathrm{H}_{2} \mathrm{O}$ & IR & 1608 vs & 1384 vs & 224 & $803 \mathrm{w}$ & $472 \mathrm{~m}$ & 321 & Bidentate chelation \\
\hline $\mathrm{CoL} \cdot 2 \mathrm{H}_{2} \mathrm{O}$ & IR & 1615 vs & $1401 \mathrm{~s}, 1379 \mathrm{~s}$ & 214,236 & $826 \mathrm{w}$ & $446 \mathrm{w}$ & 380 & Bidentate chelation \\
\hline $\mathrm{NiL} \cdot 3 \mathrm{H}_{2} \mathrm{O}$ & IR & 1623 vs & 1377 vs & 246 & $819 \mathrm{w}$ & $457 \mathrm{w}$ & 362 & Bidentate chelation \\
\hline $\mathrm{CuL} \cdot 0.5 \mathrm{H}_{2} \mathrm{O}$ & IR & $1634 \mathrm{vs}$ & 1377 vs & 257 & $823 \mathrm{~m}$ & $469 \mathrm{~m}$ & 354 & Bidentate chelation \\
\hline \multirow[t]{2}{*}{$\mathrm{ZnL} \cdot 1.5 \mathrm{H}_{2} \mathrm{O}$} & IR & 1624 vs & 1395 vs & 229 & $837 \mathrm{~s}$ & $448 \mathrm{~m}$ & 389 & Bidentate chelation \\
\hline & Raman & $1613 \mathrm{w}$ & - & - & 840 vs & - & - & \\
\hline
\end{tabular}

$53.19 \%$ ) suggests the formation of sodium carbonate (Fig. 9b; Table 4).

\section{IR and Raman spectra}

After metal complexation by 3,4-pyridinedicarboxylic and 3,5-pyridinedicarboxylic acids, some characteristic changes in the IR and Raman spectra of ligand and metal complexes occurred. It was caused by changes in the electronic charge distribution in ligand and complex molecules. In the (Fig. S1 and S2) spectra of 3d-metal complexes the bands assigned to the stretching vibrations of the carboxylate anion occurred, whereas the bands derived from the $\mathrm{C}=\mathrm{O}$ and $\mathrm{C}-\mathrm{O}$ disappeared (these bands were present in the spectra of ligand) (Table 5). In the spectra of 3,4-pyridinedicarboxylates the strong bands 
assigned to the asymmetric stretches $v_{\text {as }} \mathrm{COO}^{-}$were in the range $1620-1571 \mathrm{~cm}^{-1}$ (IR) and $1609-1575 \mathrm{~cm}^{-1}(\mathrm{Ra}-$ man), whereas symmetric stretches $\left(v_{\text {sym }} \mathrm{COO}^{-}\right)$in the range: $1406-1392 \mathrm{~cm}^{-1}$ (IR) and $1411-1401 \mathrm{~cm}^{-1}(\mathrm{Ra}-$ man). In the spectra of 3,5-pyridinedicarboxylates $v_{\text {as- }}$ $\mathrm{COO}^{-}$occurred within $1634-1603 \mathrm{~cm}^{-1}$ (IR) and 1624-1605 $\mathrm{cm}^{-1}$ (Raman) as well as symmetric stretches $\left(v_{\text {sym }} \mathrm{COO}^{-}\right)$in the range $1401-1377 \mathrm{~cm}^{-1}$ (IR) and at $1393 \mathrm{~cm}^{-1}$ (Raman). In the spectra of 3,4-pyridinedicarboxylates bands derived from the deforming in-plane vibrations of the carboxylate anion $\left(\beta_{\mathrm{sym}} \mathrm{COO}^{-}\right)$were in the range $840-834 \mathrm{~cm}^{-1}$ (IR) and $844-840 \mathrm{~cm}^{-1}$ (Raman), whereas $\beta_{\mathrm{as}} \mathrm{COO}^{-}: 499-469 \mathrm{~cm}^{-1}$ (IR) and $487-456 \mathrm{~cm}^{-1}$ (Raman). In the spectra of 3,5-pyridinedicarboxylate $\beta_{\text {sym }} \mathrm{COO}^{-}$were present within $848-803 \mathrm{~cm}^{-1}$ (IR) and $852-840 \mathrm{~cm}^{1}$ (Raman) as well as $\beta_{\mathrm{as}} \mathrm{COO}^{-}: 472-440 \mathrm{~cm}^{-1}$ (IR) and $427 \mathrm{~cm}^{-1}$ (Raman). On the basis of the differences between the wave numbers of the asymmetric and symmetric stretching vibrations of the carboxylate anion $\mathrm{COO}^{-}$, some assumption on the type of metal-ligand coordination might be stated [33, 34]. Especially the parameter $\Delta v=v_{\mathrm{as}} \mathrm{COO}^{-}-v_{\mathrm{sym}} \mathrm{COO}^{-}$might be useful [33]. In the spectra of 3,4- and 3,5-pyridinedicarboxylates, more than one band assigned to the stretching vibrations of the carboxylate anion were present. In some cases, these bands differed in the values of their wave numbers which was caused by the possibility of different type of metal coordination in one metal complex (Table 5) (Fig. 10). On the basis of the $\Delta v\left(\mathrm{COO}^{-}\right)$, it was concluded that in the copper 3,4-pyridinedicarboxylate two type of copper ion coordination occurred, i.e., bidentate bridging and monodentate. In the $\mathrm{Mn}, \mathrm{Fe}, \mathrm{Ni}$ and $\mathrm{Co}$ 3,4-pyridinedicarboxylates and $\mathrm{Mn}, \mathrm{Fe}, \mathrm{Co}, \mathrm{Ni}, \mathrm{Cu}$ and $\mathrm{Zn}$ 3,5pyridinedicarboxylates, the metal ion was coordinated by the bidentate chelation type of bonding. In the case of $\mathrm{Zn}$ 3,4-pyridinedicarboxylate, the monodentate type of coordination existed.

The effect of metal ions on the electronic system of ligands was studied on the basis of the differences between location of bands assigned to the aromatic ring vibrations in the IR and Raman spectra of ligands and their metal complexes. The decrease in the wave numbers of these bands or decrease in their intensities or their disappearance shows destabilization of the aromatic system of ligand by metal ion. In the spectra of 3,5-pyridinedicarboxylate (Table 6), most bands assigned to the ring vibrations were located at higher wave numbers comparing with the appropriate band in ligand (i.e., in the case of 19b, 12, 17b in the IR and Raman spectra; deforming in-plane vibrations of $\beta \mathrm{CH}$ ). In the spectra of metal complexes, some bands occurred (they were absent in the spectra of ligand), i.e., $8 \mathrm{~b}$ (IR) and 8b, 3 and 19b (Raman). Some bands were shifted
Fig. 10 Proposed types of metal-ligand coordination: a 3,5-pyridinedicarboxylic acid with manganese, iron, cobalt, nickel, copper, zinc (bidentate chelation); b 3,4-

pyridinedicarboxylic acid with manganese, iron, cobalt, nickel (bidentate chelation); c 3,4pyridinedicarboxylic acid with zinc (monodentate); d 3,4pyridinedicarboxylic acid with copper (bidentate bridging and monodentate) (a)

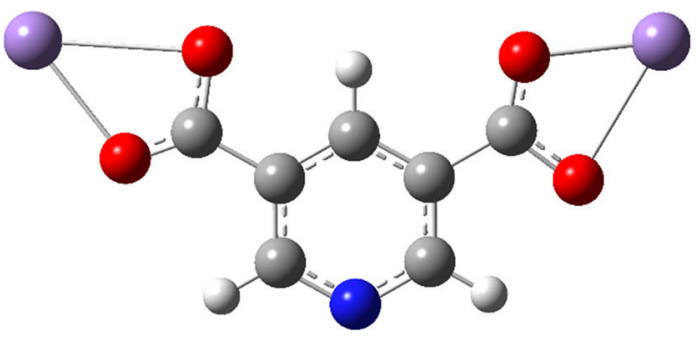

(c)

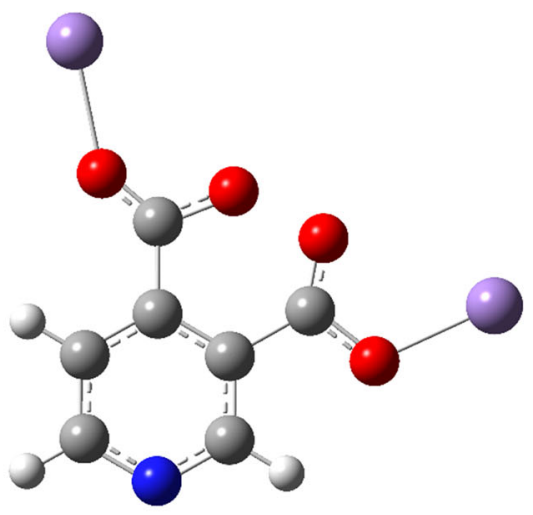

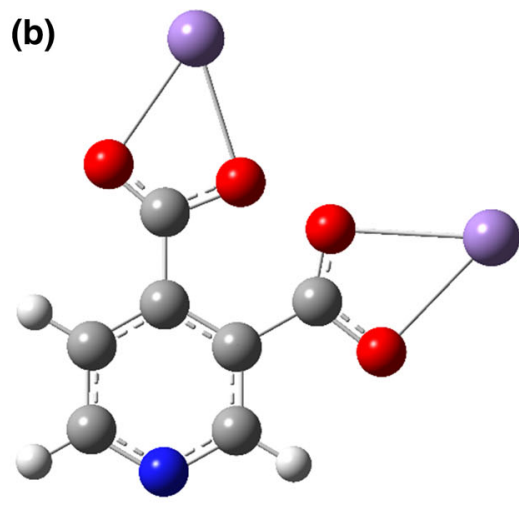

(d)

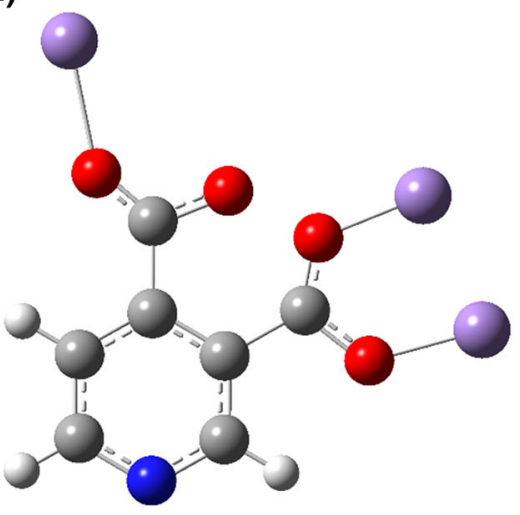


Table 6 Wave numbers and intensity of selected wave numbers from the IR and Raman spectra of 3,5-pyridinedicarboxylic acid and its metal complexes

\begin{tabular}{|c|c|c|c|c|c|c|c|c|c|c|c|c|c|}
\hline \multirow{2}{*}{\multicolumn{2}{|c|}{$3,5 \mathrm{pda}$}} & \multicolumn{11}{|c|}{ 3,5-pyridinedicarboxylate } & \multirow[t]{3}{*}{ Versanyi } \\
\hline & & \multicolumn{2}{|l|}{ Sodium } & \multicolumn{2}{|c|}{ Manganese } & \multirow{2}{*}{$\begin{array}{l}\text { Iron } \\
\text { IR }\end{array}$} & \multirow{2}{*}{$\begin{array}{l}\text { Cobalt } \\
\text { IR }\end{array}$} & \multirow{2}{*}{$\begin{array}{l}\text { Nickel } \\
\text { IR }\end{array}$} & \multirow{2}{*}{$\begin{array}{l}\text { Copper } \\
\text { IR }\end{array}$} & \multicolumn{2}{|l|}{ Zinc } & & \\
\hline IR & Raman & IR & Raman & IR & Raman & & & & & IR & Raman & & \\
\hline $1603 \mathrm{~m}$ & $1609 \mathrm{~m}$ & $1605 \mathrm{~s}$ & $1584 \mathrm{~m}$ & 1603 vs & $1604 \mathrm{~s}$ & - & - & - & - & - & $1613 \mathrm{~s}$ & $v \mathrm{CC}_{\mathrm{ar}}$ & $8 \mathrm{a}$ \\
\hline- & - & $1576 \mathrm{~s}$ & $1575 \mathrm{~m}$ & 1556 vs & $1567 \mathrm{~s}$ & $1558 \mathrm{~s}$ & 1559 vs & $1558 \mathrm{~s}$ & $1531 \mathrm{~m}$ & - & $1586 \mathrm{~s}$ & $\nu \mathrm{CC}_{\mathrm{ar}}$ & $8 \mathrm{~b}$ \\
\hline $1466 \mathrm{w}$ & $1463 \mathrm{~m}$ & $1445 \mathrm{~s}$ & $1446 \mathrm{~m}$ & $1456 \mathrm{~s}$ & $1463 \mathrm{~s}$ & - & - & - & $1474 \mathrm{w}$ & - & - & $\nu \mathrm{CC}_{\mathrm{ar}}$ & $19 \mathrm{a}$ \\
\hline $1420 \mathrm{w}$ & - & 1416 vs & $1415 \mathrm{~s}$ & $1435 \mathrm{~s}$ & - & $1437 \mathrm{~s}$ & $1440 \mathrm{~m}$ & $1433 \mathrm{~m}$ & $1445 \mathrm{~m}$ & $1450 \mathrm{~s}$ & $1453 \mathrm{~s}$ & $\nu \mathrm{CC}_{\mathrm{ar}}$ & $19 b$ \\
\hline $1304 \mathrm{~s}$ & - & $1285 \mathrm{~m}$ & $1284 \mathrm{vw}$ & $1299 \mathrm{~m}$ & $1301 \mathrm{vw}$ & $1293 \mathrm{~m}$ & $1299 \mathrm{~m}$ & $1290 \mathrm{w}$ & $1285 \mathrm{~s}$ & $1293 \mathrm{~m}$ & $1293 \mathrm{w}$ & $\beta \mathrm{CH}_{\mathrm{ar}}$ & 3 \\
\hline $1266 \mathrm{~m}$ & $1266 \mathrm{w}$ & $1239 \mathrm{w}$ & $1251 \mathrm{vw}$ & $1238 \mathrm{~m}$ & $1247 \mathrm{vw}$ & - & $1245 \mathrm{w}$ & $1248 \mathrm{w}$ & $1266 \mathrm{~m}$ & $1245 \mathrm{~m}$ & $1249 \mathrm{w}$ & $\beta \mathrm{CH}_{\mathrm{ar}}$ & $9 a$ \\
\hline $1219 \mathrm{~s}$ & $1208 \mathrm{w}$ & - & $1189 \mathrm{w}$ & $1211 \mathrm{w}$ & - & $1204 \mathrm{w}$ & $1207 \mathrm{w}$ & $1205 \mathrm{vw}$ & $1194 \mathrm{~m}$ & $1205 \mathrm{~m}$ & - & $\nu \mathrm{CN}_{\mathrm{ar}}$ & \\
\hline 1168 vs & $1150 \mathrm{vw}$ & $1151 \mathrm{~m}$ & $1151 \mathrm{w}$ & $1150 \mathrm{~m}$ & 1149 w & - & $1150 \mathrm{w}$ & $1157 \mathrm{w}$ & $1158 \mathrm{~m}$ & $1156 \mathrm{~m}$ & - & $\beta \mathrm{CH}_{\mathrm{ar}}$ & \\
\hline $1124 \mathrm{~m}$ & $1106 \mathrm{vw}$ & & $1122 \mathrm{w}$ & $1124 \mathrm{~m}$ & $1149 \mathrm{vw}$ & - & $1127 \mathrm{w}$ & $1134 \mathrm{w}$ & $1140 \mathrm{~m}$ & $1133 \mathrm{~m}$ & - & $\beta \mathrm{CH}_{\mathrm{ar}}$ & \\
\hline $1110 \mathrm{~m}$ & $1095 \mathrm{w}$ & $1099 \mathrm{~m}$ & $1089 \mathrm{w}$ & - & $1083 \mathrm{vw}$ & - & - & - & $1096 \mathrm{~m}$ & - & - & $\beta \mathrm{CH}_{\mathrm{ar}}$ & $18 \mathrm{~b}$ \\
\hline $1065 \mathrm{~s}$ & 1035 vs & $1031 \mathrm{~m}$ & $1037 \mathrm{~s}$ & $1031 \mathrm{~m}$ & 1033 vs & $1030 \mathrm{w}$ & $1034 \mathrm{w}$ & $1032 \mathrm{w}$ & $1031 \mathrm{~m}$ & $1032 \mathrm{~m}$ & 1033 vs & $\beta \mathrm{CH}_{\mathrm{ar}}$ & $18 \mathrm{a}$ \\
\hline $942 \mathrm{~m}$ & $946 \mathrm{w}$ & $962 \mathrm{w}$ & $965 \mathrm{vw}$ & $973 \mathrm{w}$ & $988 \mathrm{vw}$ & - & - & - & $977 \mathrm{w}$ & $977 \mathrm{~m}$ & $985 \mathrm{~m}$ & $\beta \mathrm{CH}_{\mathrm{ar}}$ & 12 \\
\hline $912 \mathrm{~m}$ & $919 \mathrm{w}$ & $925 \mathrm{~m}$ & $931 \mathrm{vw}$ & $935 \mathrm{~m}$ & $936 \mathrm{vw}$ & $929 \mathrm{w}$ & $938 \mathrm{w}$ & $935 \mathrm{vw}$ & $942 \mathrm{w}$ & $938 \mathrm{w}$ & $938 \mathrm{vw}$ & $\beta \mathrm{CH}_{\mathrm{ar}}$ & $17 \mathrm{~b}$ \\
\hline $854 \mathrm{w}$ & $869 \mathrm{w}$ & $824 \mathrm{~m}$ & $825 \mathrm{~m}$ & $848 \mathrm{~m}$ & $852 \mathrm{~m}$ & $815 \mathrm{w}$ & $826 \mathrm{w}$ & $837 \mathrm{w}$ & $843 \mathrm{vw}$ & $837 \mathrm{~m}$ & $840 \mathrm{~s}$ & $\gamma \mathrm{CH}_{\mathrm{ar}}$ & \\
\hline- & $801 \mathrm{~m}$ & - & - & - & $805 \mathrm{w}$ & - & - & - & - & - & $807 \mathrm{~m}$ & $\gamma \mathrm{CH}_{\mathrm{ar}}$ & $10 \mathrm{a}$ \\
\hline $783 \mathrm{~m}$ & - & $773 \mathrm{~s}$ & $776 \mathrm{w}$ & $769 \mathrm{~s}$ & $774 \mathrm{w}$ & $765 \mathrm{~m}$ & $769 \mathrm{~m}$ & $770 \mathrm{~m}$ & $755 \mathrm{~m}$ & $770 \mathrm{~s}$ & $780 \mathrm{w}$ & $\gamma \mathrm{CH}_{\mathrm{ar}}$ & \\
\hline $697 \mathrm{~s}$ & $682 \mathrm{w}$ & $687 \mathrm{~m}$ & $699 \mathrm{~m}$ & $695 \mathrm{~m}$ & $684 \mathrm{w}$ & $693 \mathrm{~m}$ & $695 \mathrm{w}$ & $668 \mathrm{~m}$ & $677 \mathrm{~m}$ & $687 \mathrm{~m}$ & $703 \mathrm{vw}$ & $\alpha C C C$ & $6 a$ \\
\hline $642 \mathrm{w}$ & $647 \mathrm{w}$ & - & $664 \mathrm{w}$ & - & - & - & - & - & - & $668 \mathrm{~m}$ & - & $\alpha \mathrm{CCC}$ & $6 \mathrm{~b}$ \\
\hline $545 \mathrm{~m}$ & $530 \mathrm{w}$ & $564 \mathrm{~m}$ & $572 \mathrm{vw}$ & - & $510 \mathrm{w}$ & $535 \mathrm{~m}$ & $528 \mathrm{vw}$ & 5312 & - & $545 \mathrm{~m}$ & - & $\alpha \mathrm{CCC}$ & \\
\hline
\end{tabular}

band intensity: $s$ strong, $m$ medium, $w$ weak, $v w$ very weak, sh shoulder; type of vibrations: $v$ stretching, $\beta$ bending in-plane, $\beta$ ring ring bending in-plane, $\gamma$ bending out-of-plane, $\alpha$ ring bending, $\varphi$ ring deformation, sym symmetric, as asymmetric

toward lower wave numbers comparing with ligand (18b, $18 \mathrm{a}, v \mathrm{CN}$ and $\gamma \mathrm{CH}$ in IR spectra). In the spectra of sodium 3,5-pyridinedicarboxylate, more bands disappeared compared with other metal complexes. In the spectrum of sodium salt, the wave numbers of some bands decreased in their values compared with the spectrum of 3,5pyridinedicarboxylic acid, whereas in the spectra of $3 \mathrm{~d}$ metal complexes wave numbers of some bands increased in comparison with the spectrum of ligand.

In the spectra of 3,4-pyridinedicarboxylates (Table 7), bands no. $8 \mathrm{~b}, 19 \mathrm{a}, 3, v \mathrm{CN}, \beta \mathrm{CH}, 12, \gamma \mathrm{CH}, 6 \mathrm{a}$ (IR) as well as $8 \mathrm{~b}, 19 \mathrm{a}, 3,12,17 \mathrm{~b}, v \mathrm{CN}$ and $6 \mathrm{a}$ (Raman) were located at higher wave numbers comparing with the appropriate ones in the spectrum of 3,4-pyridinedicarboxylic acid. Whereas bands no. 9a, 18b and $\gamma \mathrm{CH}$ (IR) and 19a, 8a (Raman) were shifted toward lower wave numbers comparing with ligand. Bands no. 19b and 6b (IR) as well as $19 \mathrm{~b}$ and $\gamma \mathrm{CH}$ (Raman) were present in the spectra of acids and disappeared in the spectra of complexes.

Comparing the IR and Raman spectra of 3,4- and 3,5pyridinedicarboxylic acids and their 3d-metal complexes, it could be concluded that $3 \mathrm{~d}$-transitional metal stabilized the electronic system of ligands (similarly as it was stated in the case of 3d-metal complexes of pyridinemonocarboxylic acid, i.e., picolinic acid) [22]. 3d-Metals strongly affected the electronic system of 3,4-pyridinedicarboxylic acid than 3,5-pyridinedicarboxylic acid (on the basis of the changes in the location and intensity of the aromatic ring vibrations in the spectra of ligands and complexes). The carboxylic groups in the 3,5-pyridinedicarboxylic acid are symmetrically located taking into account the location of the nitrogen atom in the aromatic ring. This causes a symmetric distribution of the electronic charge in the molecule of 3,5pyridinedicarboxylic acid. In the case of 3,4-pyridinedicarboxylic acid, the carboxylic groups are unsymmetrically located which translates into unsymmetrically distributed electronic charge in 3,4-pyridinedicarboxylic acid molecule. The differences in the location of the carboxylic groups and the electronic charge distribution in pyridinedicarboxylic acids cause that $3 \mathrm{~d}$-transition metal ions in different way affect the molecular structure of studied ligands. This causes different physico-chemical and thermal properties of studied metal complexes. The similar conclusion was described in the papers devoted to the salts 
Table 7 Wave numbers and intensity of selected wave numbers from the IR and Raman spectra of 3,4-pyridinedicarboxylic acid and its metal complexes

\begin{tabular}{|c|c|c|c|c|c|c|c|c|c|c|c|c|c|}
\hline \multirow{2}{*}{\multicolumn{2}{|c|}{$3,4 \mathrm{pda}$}} & \multicolumn{11}{|c|}{ 3,4-pyridinedicarboxylate } & \multirow[t]{3}{*}{ Versanyi } \\
\hline & & \multicolumn{2}{|l|}{ Sodium } & \multicolumn{2}{|c|}{ Manganese } & \multirow{2}{*}{$\begin{array}{l}\text { Iron } \\
\text { IR }\end{array}$} & \multirow{2}{*}{$\begin{array}{l}\text { Cobalt } \\
\text { IR }\end{array}$} & \multirow{2}{*}{$\begin{array}{l}\text { Nickel } \\
\text { IR }\end{array}$} & \multirow{2}{*}{$\begin{array}{l}\text { Copper } \\
\text { IR }\end{array}$} & \multicolumn{2}{|l|}{ Zinc } & & \\
\hline IR & Raman & IR & Raman & IR & Raman & & & & & IR & Raman & & \\
\hline 1607 vs & $1613 \mathrm{~m}$ & - & $1606 \mathrm{w}$ & - & $1608 \mathrm{~s}$ & - & - & - & - & & $1609 \mathrm{~s}$ & $\nu \mathrm{CC}_{\mathrm{ar}}$ & $8 \mathrm{a}$ \\
\hline- & - & - & $1581 \mathrm{w}$ & - & $1575 \mathrm{~m}$ & - & - & - & - & & $1588 \mathrm{~m}$ & $v \mathrm{CC}_{\mathrm{ar}}$ & \\
\hline $1521 \mathrm{~m}$ & $1534 \mathrm{~m}$ & $1546 \mathrm{~m}$ & $1548 \mathrm{w}$ & - & $1548 \mathrm{~m}$ & - & - & - & - & $1558 \mathrm{~s}$ & $1554 \mathrm{~s}$ & $\nu \mathrm{CC}_{\mathrm{ar}}$ & $8 \mathrm{~b}$ \\
\hline $1472 \mathrm{~m}$ & $1492 \mathrm{~m}$ & $1481 \mathrm{~s}$ & $1488 \mathrm{w}$ & $1491 \mathrm{~m}$ & $1492 \mathrm{~s}$ & $1488 \mathrm{~s}$ & $1493 \mathrm{~m}$ & $1490 \mathrm{~s}$ & $1491 \mathrm{~m}$ & $1491 \mathrm{~m}$ & $1494 \mathrm{~s}$ & $\nu \mathrm{CC}_{\mathrm{ar}}$ & $19 \mathrm{a}$ \\
\hline $1456 \mathrm{~m}$ & $1453 \mathrm{vw}$ & - & $1424 \mathrm{~s}$ & - & - & - & - & - & - & - & - & $\nu \mathrm{CC}_{\mathrm{ar}}$ & $19 b$ \\
\hline- & $1399 \mathrm{~s}$ & - & $1382 \mathrm{w}$ & - & - & - & - & - & - & - & - & $v \mathrm{CH}_{\mathrm{ar}}$ & 14 \\
\hline $1276 \mathrm{w}$ & $1285 \mathrm{~m}$ & 1273 w & $1287 \mathrm{vw}$ & $1285 \mathrm{w}$ & $1285 \mathrm{w}$ & 1283 w & $1286 \mathrm{w}$ & $1286 \mathrm{w}$ & $1283 \mathrm{w}$ & $1286 \mathrm{w}$ & $1287 \mathrm{w}$ & $\beta \mathrm{CH}_{\mathrm{ar}}$ & 3 \\
\hline $1260 \mathrm{w}$ & $1251 \mathrm{~s}$ & $1241 \mathrm{w}$ & $1239 \mathrm{vw}$ & $1229 \mathrm{w}$ & $1222 \mathrm{w}$ & - & $1231 \mathrm{~m}$ & $1235 \mathrm{w}$ & - & $1234 \mathrm{w}$ & $1237 \mathrm{~m}$ & $\beta \mathrm{CH}_{\mathrm{ar}}$ & $9 a$ \\
\hline 1177 w & 1170 vs & 1197 w & 1197 m & $1200 \mathrm{w}$ & 1203 w & $1191 \mathrm{w}$ & 1195 w & 1194 w & $1192 \mathrm{~m}$ & 1195 w & $1201 \mathrm{w}$ & $\nu \mathrm{CN}_{\mathrm{ar}}$ & \\
\hline $1157 \mathrm{~m}$ & - & $1160 \mathrm{w}$ & $1170 \mathrm{w}$ & $1171 \mathrm{w}$ & $1170 \mathrm{~m}$ & $1167 \mathrm{~m}$ & 1167 w & 1167 w & $1166 \mathrm{~m}$ & $1167 \mathrm{w}$ & $1168 \mathrm{~m}$ & $\beta \mathrm{CH}_{\mathrm{ar}}$ & \\
\hline- & $1120 \mathrm{~m}$ & $1126 \mathrm{vw}$ & $1127 \mathrm{vw}$ & $1124 \mathrm{w}$ & $1125 \mathrm{w}$ & $1122 \mathrm{~m}$ & $1123 \mathrm{w}$ & $1124 \mathrm{w}$ & $1120 \mathrm{~m}$ & $1124 \mathrm{w}$ & $1127 \mathrm{w}$ & $\beta \mathrm{CH}_{\mathrm{ar}}$ & \\
\hline $1078 \mathrm{~s}$ & 1064 vs & $1052 \mathrm{~m}$ & $1054 \mathrm{w}$ & $1058 \mathrm{w}$ & $1058 \mathrm{~m}$ & $1059 \mathrm{~m}$ & 1064 w & 1068 w & $1069 \mathrm{~m}$ & 1072 w & $1071 \mathrm{~m}$ & $\beta \mathrm{CH}_{\mathrm{ar}}$ & $18 \mathrm{~b}$ \\
\hline $973 \mathrm{~m}$ & $975 \mathrm{w}$ & $977 \mathrm{w}$ & - & $981 \mathrm{vw}$ & $979 \mathrm{vw}$ & - & $993 \mathrm{w}$ & - & - & $988 \mathrm{w}$ & $990 \mathrm{vw}$ & $\beta \mathrm{CH}_{\mathrm{ar}}$ & 12 \\
\hline- & $929 \mathrm{vw}$ & $930 \mathrm{vw}$ & - & $955 \mathrm{vw}$ & $950 \mathrm{vw}$ & - & $952 \mathrm{w}$ & - & $947 \mathrm{w}$ & $950 \mathrm{w}$ & $944 \mathrm{vw}$ & $\beta \mathrm{CH}_{\mathrm{ar}}$ & $17 \mathrm{~b}$ \\
\hline $844 \mathrm{~s}$ & $836 \mathrm{vw}$ & $853 \mathrm{~m}$ & $867 \mathrm{vw}$ & $862 \mathrm{w}$ & $844 \mathrm{~m}$ & $853 \mathrm{~m}$ & $840 \mathrm{w}$ & $836 \mathrm{~m}$ & $837 \mathrm{~m}$ & $838 \mathrm{w}$ & $840 \mathrm{~s}$ & $\gamma \mathrm{CH}_{\mathrm{ar}}$ & \\
\hline- & $819 \mathrm{~m}$ & - & $826 \mathrm{~m}$ & - & - & - & - & - & - & - & - & $\gamma \mathrm{CH}_{\mathrm{ar}}$ & $10 \mathrm{a}$ \\
\hline $779 \mathrm{~m}$ & $774 \mathrm{vw}$ & $786 \mathrm{~m}$ & $784 \mathrm{vw}$ & $790 \mathrm{~m}$ & $790 \mathrm{vw}$ & $772 \mathrm{~m}$ & $782 \mathrm{w}$ & $782 \mathrm{~m}$ & $779 \mathrm{~m}$ & $785 \mathrm{w}$ & - & $\gamma \mathrm{CH}_{\mathrm{ar}}$ & \\
\hline $731 \mathrm{~m}$ & $732 \mathrm{vw}$ & $708 \mathrm{~m}$ & $709 \mathrm{vw}$ & $708 \mathrm{~m}$ & $707 \mathrm{vw}$ & $707 \mathrm{~m}$ & $714 \mathrm{~m}$ & $718 \mathrm{~m}$ & $722 \mathrm{~m}$ & $722 \mathrm{w}$ & $734 \mathrm{vw}$ & $\alpha C C C$ & \\
\hline $677 \mathrm{w}$ & $672 \mathrm{~m}$ & $678 \mathrm{~m}$ & $684 \mathrm{w}$ & $678 \mathrm{~s}$ & $684 \mathrm{w}$ & $677 \mathrm{~s}$ & $681 \mathrm{~m}$ & $683 \mathrm{~m}$ & $685 \mathrm{~m}$ & $684 \mathrm{~m}$ & $686 \mathrm{~m}$ & aCCC & $6 a$ \\
\hline $660 \mathrm{~s}$ & - & $646 \mathrm{~m}$ & - & - & - & - & - & - & - & $650 \mathrm{vw}$ & - & aCCC & $6 \mathrm{~b}$ \\
\hline $587 \mathrm{~m}$ & $585 \mathrm{vw}$ & $572 \mathrm{w}$ & $572 \mathrm{vw}$ & $595 \mathrm{~m}$ & $599 \mathrm{vw}$ & $582 \mathrm{~m}$ & $610 \mathrm{w}$ & $615 \mathrm{~m}$ & $609 \mathrm{w}$ & $606 \mathrm{w}$ & $612 \mathrm{vw}$ & $\alpha C C C$ & \\
\hline
\end{tabular}

band intensity: $s$ strong, $m$ medium, $w$ weak, $v w$ very weak, $s h$ shoulder; type of vibrations: $v$ stretching, $\beta$ bending in-plane, $\beta$ ring ring bending in-plane, $\gamma$ bending out-of-plane, $\alpha$ ring bending, $\varphi$ ring deformation, sym symmetric, as asymmetric

and metal complexes of 2,3- and 4-pyridinecarboxylic acids $[19,20]$.

\section{Conclusions}

The thermal decomposition of the two series of hydrated complexes of $\mathrm{Mn}(\mathrm{II}), \mathrm{Fe}(\mathrm{III}), \mathrm{Co}(\mathrm{II}), \mathrm{Ni}(\mathrm{II}), \mathrm{Cu}(\mathrm{II})$ and $\mathrm{Zn}$ (II) with 3,4- and 3,5-pyridinedicarboxylic acids is a multistage process. At first the complexes lose all water molecules in one or two steps which are connected with endothermic effects. After dehydration, in the next stages, the anhydrous complexes decompose exothermally which can be also attributed to oxidation of organic matter and the gaseous products evolved during thermal decomposition. Finally, metal oxides are formed. Larger thermal stability is observed for anhydrous complexes of 3,5-pda ligand which can be a result of more symmetric structure and charge distribution of this ligand contrary to the thermal stability of 3,4-pda series. The differences in the location of the carboxylic groups and the electronic charge distribution in pyridinedicarboxylic acids cause that $3 \mathrm{~d}$-transition metal ions in different way affect the molecular structure of studied ligands. This causes different physico-chemical and thermal properties of studied metal complexes.

Acknowledgements This work was financially supported by Bialystok University of Technology in the frame of funding for statutory research (No. S/WBiIŚ/1/2012).

Open Access This article is distributed under the terms of the Creative Commons Attribution 4.0 International License (http://crea tivecommons.org/licenses/by/4.0/), which permits unrestricted use, distribution, and reproduction in any medium, provided you give appropriate credit to the original author(s) and the source, provide a link to the Creative Commons license, and indicate if changes were made.

\section{References}

1. Stearns DM, Armstrong WII. Mononuclear and binuclear chromium(III) picolinate complexes. Inorg Chem. 1992;31:5178-84.

2. Song R, Kim KM, Sohn YS. Synthesis and properties of (diamine)platinum(II) complexes of pyridine carboxylate isomers and their antitumor activity. Inorg Chim Acta. 1999;292:238-43. 
3. Chakov NE, Collins RA, Vincent JB. A re-investigation the electronic spectra of chromium(III) picolinate complexes and high yield synthesis and characterization of $\mathrm{Cr}_{2}(\mu-\mathrm{OH})_{2}(\mathrm{pic})_{4}$ $5 \mathrm{H}_{2} \mathrm{O}$ (Hpic = picolinic acid). Polyhedron. 1999;18:2891-7.

4. Ding H, Olson LK, Caruso JA. Elemental speciation for chromium in chromium picolinate products. Spectrochim Acta B. 1996;51:1801-12.

5. Tienken R, Kersten S, Frahm J, Hüther L, Meyer U, Huber K, Rehage J, Dänicke S. Effects of prepartum dietary energy level and nicotinic acid supplementation on immunological, hematological and biochemical parameters of periparturient dairy cows differing in parity. Animals. 2015;5:910-33.

6. Wang Z, Yang L, Cui S, Liang Y, Zhang X. Synthesis and antihypertensive effects of the twin drug of nicotinic acid and quercetin tetramethyl ether. Molecules. 2014;19:4791-801.

7. Safarova MS, Trukhacheva EP, Ezhov MV, Afanas'eva OI, Afanas'eva MI, Tripoten' MI, Liakishev AA, Pokrovskiǐ SN. Pleiotropic effects of nicotinic acid therapy in men with coronary heart disease and elevated lipoprotein(a) levels. Kardiologiia. 2011;51(5):9-16.

8. Rebello T, Lönnerdal B, Hurley LS. Picolinic acid in milk, pancreatic juice, and intestine: inadequate for role in zinc absorption. Am J Clin Nutr. 1982;35(1):1-5.

9. Suzuki K, Yasuda M, Yamasaki K. Constants of picolinic and quinolinic acid chelates of bivalent metals. J Phys Chem. 1957;61:229-31.

10. Menard MP, Cousins RJ. Effect of citrate, glutathione and picolinate on zinc transport by brush border membrane vesicles from rat intestine. J Nutr. 1983;113:1653-6.

11. Dazzi C, Candiano G, Massazza S, Ponzetto A, Varesio L. New high-performance liquid chromatographic method for the detection of picolinic acid in biological fluids. J Chromatogr B Biomed Sci Appl. 2001;751(1):61-8.

12. Zhang HK, Zhang X, Mao BZ, Qun L, Zu Hua H. Alpha-picolinic acid, a fungal toxin and mammal apoptosis-inducing agent, elicits hypersensitive-like response and enhances disease resistance in rice. Cell Res. 2004;14(1):27-33.

13. Bosco MC, Rapisarda A, Massazza S, Melillo G, Young H, Varesio L. The tryptophan catabolite picolinic acid selectively induces the chemokines macrophage inflammatory protein-1-alpha and 1-beta in macrophages. J Immunol. 2000;164:3283-91.

14. Frumento G, Rotondo R, Tonetti M, Damonte G, Benatti U, Ferrara GB. Tryptophan-derived catabolites are responsible for inhibition of $\mathrm{T}$ and natural killer cell proliferation induced by indoleamine 2,3-dioxygenase. J Exp Med. 2002;196(4):459-68.

15. Roje S. Vitamin B biosynthesis in plants. Phytochemistry. 2007;68: 1904-21.

16. Grundy SM, Mok HYI, Zech L, Berman M. Influence of nicotinic acid on metabolism of cholesterol and triglycerides in man. J Lipid Res. 1981;22:24-36.

17. Nie F-M, Fang T, Wang S-Y, Ge H-Y. Synthesis and structures of pyridinecarboxylate-containing zinc(II) complexes in dien and tren system. Inorg Chim Acta. 2011;365:325-32.

18. Schwarcz R. The kynurenine pathway of tryptophan degradation as a drug target. Curr Opin Pharmacol. 2004;4(1):12-7.

19. Koczoń P, Dobrowolski JC, Lewandowski W, Mazurek AP. Experimental and theoretical IR and Raman spectra of picolinic, nicotinic and isonicotinic acid. J Mol Struct. 2003;655:89-95.
20. Koczoń P, Hrynaszkiewicz T, Świsłocka R, Samsonowicz M, Lewandowski W. Spectroscopic (Raman, FT-IR, and NMR) study of alkaline metal nicotinates and isonicotinates. Vib Spectrosc. 2003;33:215-22.

21. Koczoń P, Piekut J, Borawska M, Lewandowski W. Vibrational structure and antimicrobial activity of selected isonicotinates, potassium picolinate and nicotinate. J Mol Struct. 2003;651653:651-6.

22. Świderski G, Kalinowska M, Wojtulewski S, Lewandowski W. Experimental (FT-IR, Raman, ${ }^{1} \mathrm{H}$ NMR) and theoretical study of magnesium, calcium, strontium and barium picolinates. Spectrochim Acta A. 2006;64:24-33.

23. Kalinowska M, Borawska M, Świsłocka R, Piekut J, Lewandowski W. Spectroscopic (IR, Raman, UV, ${ }^{1} \mathrm{H}$ and ${ }^{13} \mathrm{C}$ NMR) and microbiological studies of $\mathrm{Fe}(\mathrm{III}), \mathrm{Ni}(\mathrm{II}), \mathrm{Cu}(\mathrm{II}), \mathrm{Zn}$ (II) and Ag(I) picolinates. J Mol Struct. 2007;834-836:419-25.

24. Whitfield T, Zheng LM, Wang X, Jacobson AJ. Syntheses and characterization of $\mathrm{Co}($ pydc) $(\mathrm{H} 2 \mathrm{O}) 2$ and $\mathrm{Ni}($ pydc) $(\mathrm{H} 2 \mathrm{O})$ (py$\mathrm{dc}=3,5$-pyridinedicarboxylate). Solid State Sci. 2001;3:82983525.

25. Łyszczek R, Mazur L. Polynuclear complexes constructed by lanthanides and pyridine-3,5-dicarboxylate ligand: structures, thermal and luminescent properties. Polyhedron. 2012;41:7-19.

26. Starosta W, Ptasiewicz-Bak H, Leciejewicz J. The crystal structure of an ionic calcium complex with pyridine-3,5-dicarboxylate and water ligand. J Coord Chem. 2003;56(1):33-9.

27. Tong ML, Wang J, Hu S. Synthesis, structures and magnetic properties of two 3D 3,4-pyridinedicarboxylate bridged manganese(II) coordination polymers incorporating 1D helical $\mathrm{Mn}$ (carboxylate) 2 chain or $\mathrm{Mn} 3(\mathrm{OH}) 2$ chain. J Solid State Chem. 2005; 178:1518-25.

28. Jabłońska-Wawrzycka A, Zienkiewicz M, Hodorowicz M, Rogala P, Barszcz B. Thermal behavior of manganese(II) complexes with pyridine-2,3-dicarboxylic acid. J Them Anal Calorim. 2012; 110:1367-76.

29. Jabłońska-Wawrzycka A, Zienkiewicz M, Barszcz B, Rogala P. Thermoanalytical study of selected transition bivalent metal complexes with 5-calbaldehyde-4-methylimidazole. J Them Anal Calorim. 2012;109:735-43.

30. Barszcz B, Masternak J, Surga W. Thermal properties of Ca(II) and $\mathrm{Cd}(\mathrm{II})$ complexes of pyridinedicarboxylates. Correlation with crystal structures. J Them Anal Calorim. 2010;101:633-9.

31. Teixeira JA, Nunes WDG, Colman TAD, Nascimento ALCS, Caires FJ, Campos FX, Galico DA, Ionashiro M. Thermal and spectroscopic study to investigate p-aminobenzoic acid, sodium p-aminobenzoate and its compounds with some lighter trivalent lanthanides. Thermochim Acta. 2016;624:59-68.

32. Volkova TV, Blokhina SV, Ryzhakov AM, Sharapova AV, Olkhovich MV, Perlovich GL. Vapor pressure and sublimation thermodynamics of aminobenzoic acid, nicotinic acid, and related amido-derivatives. J Them Anal Calorim. 2016;123:841-9.

33. Nakamoto K. Infrared and Raman spectra of inorganic and coordination compounds. New York: Wiley; 1986.

34. Deacon GB, Philips RJ. Relationships between the carbon-oxygen stretching frequencies of carboxylato complexes and the type of carboxylate coordination. Coord Chem Rev. 1980;33:227. 